\section{Pacific Northwest}

National Laboratory

Operated by Battelle for the

U.S. Department of Energy

\title{
A Catalog of Vadose Zone Hydraulic Properties for the Hanford Site
}

\author{
E. J. Freeman \\ R. Khaleel (a) \\ P. R. Heller (b)
}

September 2004

(a) Fluor Federal Services, Richland, Washington

(b) UFA Ventures, Richland, Washington

Prepared for the U.S. Department of Energy under Contract DE-AC06-76RL01830 


\section{DISCLAIMER}

This report was prepared as an account of work sponsored by an agency of the United States Government. Reference herein to any specific commercial product, process, or service by trade name, trademark, manufacturer, or otherwise does not necessarily constitute or imply its endorsement, recommendation, or favoring by the United States Government or any agency thereof, or Battelle Memorial Institute.

\section{PACIFIC NORTHWEST NATIONAL LABORATORY \\ operated by \\ BATTELLE \\ for the \\ UNITED STATES DEPARTMENT OF ENERGY \\ under Contract DE-AC06-76RL01830}

Printed in the United States of America

Available to DOE and DOE contractors from the

Office of Scientific and Technical Information, P.O. Box 62, Oak Ridge, TN 37831; prices available from (615) 576-8401.

Available to the public from the National Technical Information Service, U.S. Department of Commerce, 5285 Port Royal Rd., Springfield, VA 22161

This document was printed on recycled paper. 


\title{
A Catalog of Vadose Zone Hydraulic Properties for the Hanford Site
}

\author{
E. J. Freeman \\ R. Khaleel \\ P. R. Heller
}

September 2001

Prepared for

the U.S. Department of Energy

under Contract DE-AC06-76RL01830

Pacific Northwest National Laboratory

Richland, Washington 99352 


\section{Summary}

For more than 50 years, contaminants from nuclear weapons production were released to the ground at Hanford, Washington. During operations, liquid and solid waste was disposed to the ground, where the contaminants could then move through the unsaturated sediment and into the groundwater. Once in the groundwater, the contaminants are transported with the groundwater that may be withdrawn at wells or discharged to the Columbia River. To predict contaminant release to groundwater, it is necessary to understand the hydraulic properties of the material between the release point and the water table. Measurements of the hydraulic properties of the Hanford unsaturated sediment that buffers the water table are available for many areas of the site; however, the documentation is not well cataloged nor is it easily accessible. The purpose of this report is to identify what data is available for characterization of the unsaturated hydraulic properties at Hanford and where it can be found.

This report is arranged into five sections and four appendices. Chapter 1 contains the purpose of this report, identifies other data compilations that are relevant to unsaturated flow issues, and identifies key points of contact at Hanford contractors who are involved with resolution of unsaturated flow issues. Chapter 2 is a brief overview of the soil physics approach and topics of consideration at Hanford. Chapter 3 identifies laboratory and field measurement facilities where Hanford unsaturated flow data is collected. The information in this section includes the hydraulic properties measured and the operational status of each facility. Chapter 4 describes how the references in Appendix B are organized. Chapter 5 contains the conclusion statement. This last section is a discussion of the preceding sections and the appendices and identifies where documentation and other information resides. The four appendices include a list of hydraulic parameters and references to literature sources that are relevant to each category (Appendix A), a bibliography of Hanford related documents with content summaries (Appendix B), a table of sites that have measured data and the number of measurements by parameters type (Appendix $C$ ), and a list of the primary references (Appendix D) sorted by year of publication. 


\section{Contents}

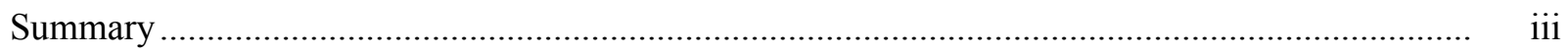

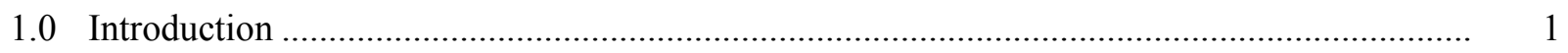

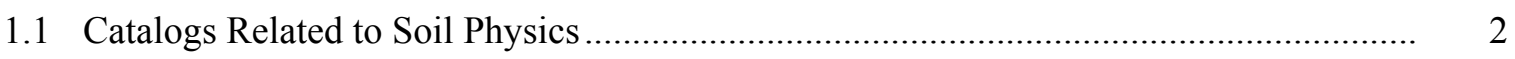

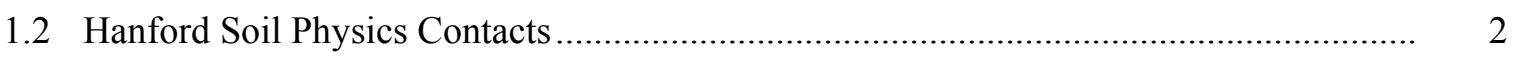

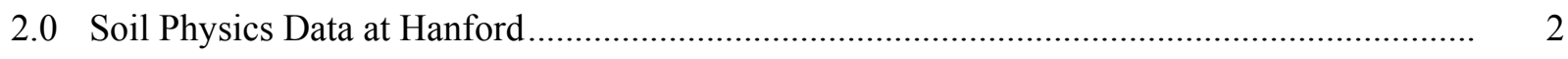

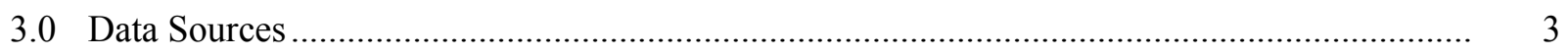

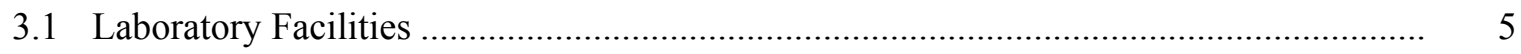

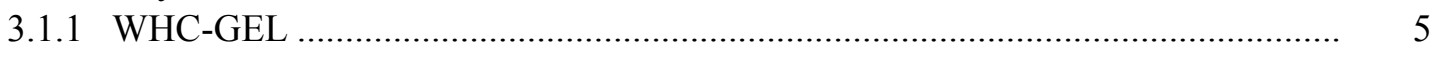

3.1.2 Pacific Northwest National Laboratory ............................................................ 5

3.1.3 Unsaturated Flow Apparatus ............................................................................... 6

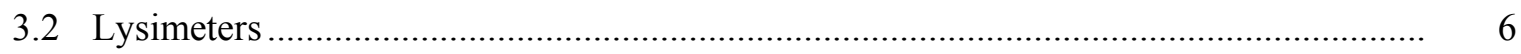

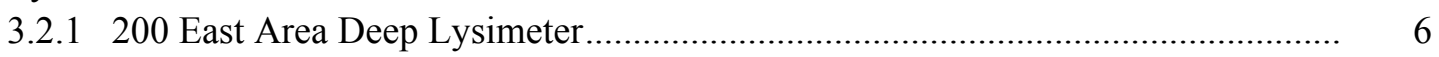

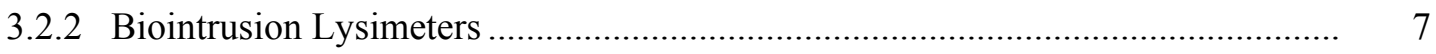

3.2.3 Field Lysimeter Test Facility ......................................................................... 7

3.2.4 Small Tube Lysimeter Facility ............................................................................ 7

3.2.5 Vadose Zone Field Site 300N …….................................................................. 7

3.2.6 Special Waste Test Facility ............................................................................ 8

3.2.7 Grout Waste Test Facility …........................................................................... 8

3.2.8 ALE Reserve Lysimeters .......................................................................... 8

3.2.9 Sold Waste Landfill Basin Lysimeter ................................................................. 8

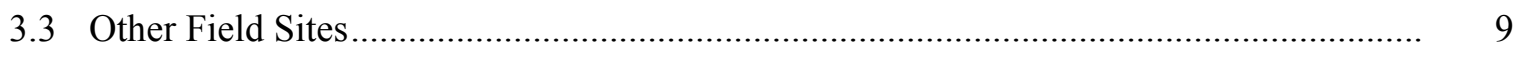

3.3.1 Sisson-Lu Injection Site ......................................................................... 9

3.3.2 Mock Tank Facility ........................................................................................... 9

3.3.3 Prototype Surface Barrier Facility ............................................................. 10

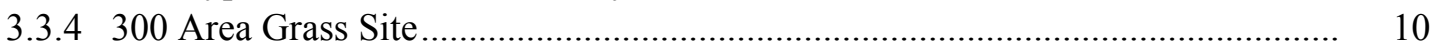

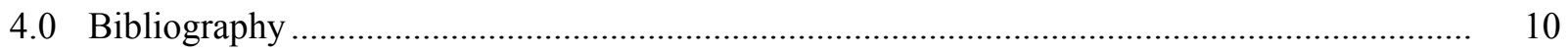

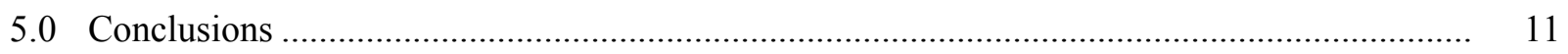

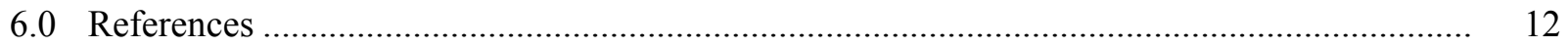


Appendix A - Parameter Characteristics and Related References .............................................. A.1

Appendix B - Bibliography of Vadose Zone Hydraulic Properties for the Hanford Site................. B. B

Appendix C - Table of Hanford Sites and Soil Physics Measurements ........................................ C.1

Appendix D - Sorted List of Publication Type, Author List, and Publication Year ....................... D. 1

\section{Figure}

1 Location of Lysimeters and Other Field Sites at the Hanford Site ......................................... 4

\section{Table}

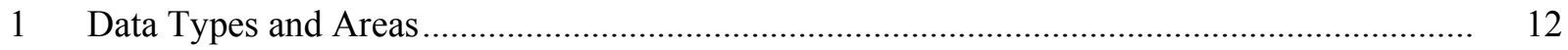




\subsection{Introduction}

Release of contaminants to the ground from nuclear weapons production facilities at Hanford, Washington, occurred for more than 50 years. Once released to the ground, effluent water and waste migrate through the unsaturated soil column (vadose zone) before arriving at the saturated, water table. During transport in the vadose zone, some of the contaminants are adsorbed by the soil matrix and are subject to prolonged release to the groundwater for an extended period of time. The release rates to groundwater depend on the total fluid and waste volume, the adsorption of contaminants onto the soil, ion exchange, current moisture distribution in the sediment, recharge rates, sediment texture and structure, and depth to the water table. To understand the migration path and time for a contaminant to pass through the vadose zone, it is necessary to understand the hydraulic, physical, and chemical conditions that exist in the sediment. This is achieved, in part, by knowledge of the vadose properties and the ability to assign the correct properties on a site-specific basis.

The Characterization of Systems (CoS) Task under the Groundwater/Vadose Zone Integration Project is responsible for establishing a consistent set of data, parameters, and conceptual models to support efforts at the Hanford Site to estimate contaminant migration and impacts (DeLamare 2000). As part of these efforts, CoS scientists are assembling a series of catalogs to identify the depth and breadth of existing data and to facilitate access to those data. The preparation of these catalogs is to facilitate the development of comprehensive, useable, and scientifically defensible database(s). However, it is also envisioned that these catalogs will be "living documents" that will continue to evolve, as other existing data is found and new data collected.

Hanford data are used by scientists studying the vadose zone onsite to provide input for unsaturated flow and transport models. These models are then used to assess the past, present, and future impact that waste operations have on regional health and the environment. Throughout this document, the terms "soil physics" and "vadose zone hydrology" are used interchangeably.

This document is separated into five main sections. Chapter 1 is this introduction, other closely related bibliographic sources, and a list of the Hanford soil physics contacts. Chapter 2 is a brief overview of some aspects of Hanford soil physics. Chapter 3 is a description of the field and laboratory facilities from which measurements are derived. Chapter 4 is a brief perspective of what went into putting together the reference list. Chapter 5 is the conclusion. Appendix A is a table listing parameters characteristics followed by a list of publication reference indexes from Appendix B. Appendix B is an annotated bibliography of documents that reference work that involved data collection activities or analysis of Hanford derived vadose data. This appendix is organized alphabetically by lead author. Each citation also is numbered. This numbering system identifies the reference in Appendix D, where the documents are sorted by year of publication. Appendix $C$ is a spreadsheet of the sites and types of data used by the soil physics community at Hanford. Appendix D is a table with document numbers, authors list, and year of publication. This table is sorted by year of publication. 


\subsection{Catalogs Related to Soil Physics}

Three separate catalogs are being prepared in parallel to document the existing vadose zone data. These include the geologic data, vadose-zone hydraulic-property data, and geochemical data. These catalogs join an already existing catalog on surface and borehole geophysical data (Last and Horton 2000) and a catalog on release mechanisms (in preparation). A bibliography was published by Gee and Heller (1985) to focus on the physical properties of Hanford soil as they relate to recharge. The references in Gee and Heller are included in Appendix B so that all relevant references could be maintained in one place. The contents of this report are intended to add to the previous bibliographic work and identify additional sources of information that are pertinent to properties of soil physics data at Hanford.

\subsection{Hanford Soil Physics Contacts}

The soil physics contacts are key contractor personnel who are actively involved in projects where soil physics data is collected or used. Personnel include a wide range of expertise including modeling, laboratory and field measurements, and project management. This is not necessarily an exhaustive list of experts in the field, but rather contacts among the primary contractors at Hanford who can direct inquiries to the appropriate expert. Contact personnel among the Hanford contractors include

$\begin{array}{lll}\text { Glendon Gee } & \text { Pacific Northwest National Laboratory } & \text { (509) } 372-6096 \\ \text { Raz Khaleel } & \text { Fluor Federal Services } & \text { (509) } 376-6903 \\ \text { John Relyea } & \text { Fluor Hanford } & \text { (509) } 376-4977 \\ \text { Paula Heller } & \text { UFA ventures } & \text { (509) } 375-3258\end{array}$

\subsection{Soil Physics Data at Hanford}

The purpose of this document is to collect pertinent references about soil physical properties measured at Hanford. Two general categories of data are identified as (1) laboratory measurements and (2) field measurements. The types of laboratory measurements typically collected are water content, pressure head, saturated and unsaturated hydraulic conductivity, particle-size distribution, particle density, and bulk density. Field measurements include drainage, soil water storage, soil moisture profiles, and air permeability measurements. The physical and hydraulic properties input for the unsaturated data fields in numerical models are predominantly derived from the laboratory measurements.

An advantage of using data from laboratory measurements is that the water characteristic curves for water retention and hydraulic conductivity of the sediment are derived for a large range of tensions, from wet to very dry, in a controlled environment. The same is not true of field measurements. A disadvantage is that the data used for modeling are typically derived from laboratory measurements of semidisturbed or repacked samples. The laboratory samples, though providing a full range of water content, pressure head, and/or unsaturated hydraulic conductivity values, are only representative of a small volume 
of the actual heterogeneous sedimentary column. Consequently, using a single sediment sample to define a formation scale feature does not adequately capture the complexity in the formation.

The field data typically supply information pertinent to drainage fluxes (recharge), material location in the profile, and initial hydraulic conditions (water content and pressure head). Environmental factors accounted for in field campaigns include consideration of vegetation cover or lack thereof, sedimentary texture and layering, and climate conditions (temperature, precipitation, wind). Field studies are conducted at well-defined facilities such as lysimeters, where the sediment physical properties are well known in the control volume or in less well-characterized settings where observation wells are used to monitor soil water conditions in the naturally deposited sediment. Measured hydraulic properties data are often entered into the models as data tables measured for a parameter range (as a function of pressure head or water content) or as calculated parameter input to equations.

The data sources referenced here are of three types:

- raw data collected in the laboratory or the field

- publications that contain raw data and calculated values derived from the data

- publications where the raw data has been translated to function parameters.

The best data to work with is the raw data because the information can then be manipulated by whatever methods an investigator may like. With processed data, the investigator is forced to use the modified parameters based on assumptions and modification by the previous user. If an error was introduced into the calculations or an improved method is available to derive parameters, there may not be enough information about the derived parameters to back out the original values. Also, during processing, the data is approximated, so unless the exact procedure is known, the data cannot be exactly recovered.

\subsection{Data Sources}

Sediment samples are collected from field sites and sent to laboratories for analysis, or measurements are taken in the field at instrument ports or at access tubes. Laboratory analyses of the hydraulic properties of samples collected at Hanford have been performed at three soils laboratories:

1. Westinghouse Hanford Company Geotechnical Engineering Lab (WHC-GEL)

2. Pacific Northwest National Laboratory (PNNL)

3. UFA Ventures.

Most of the measurement techniques employed in the laboratory and in the field are explained in detail in Klute (1986). Field sites are chiefly lysimeters and cased boreholes installed in the Hanford sediment. Figure 1 shows the locations of the lysimeters and other field sites at Hanford. The following subsections are a brief description of the laboratories and various field experimental sites. 


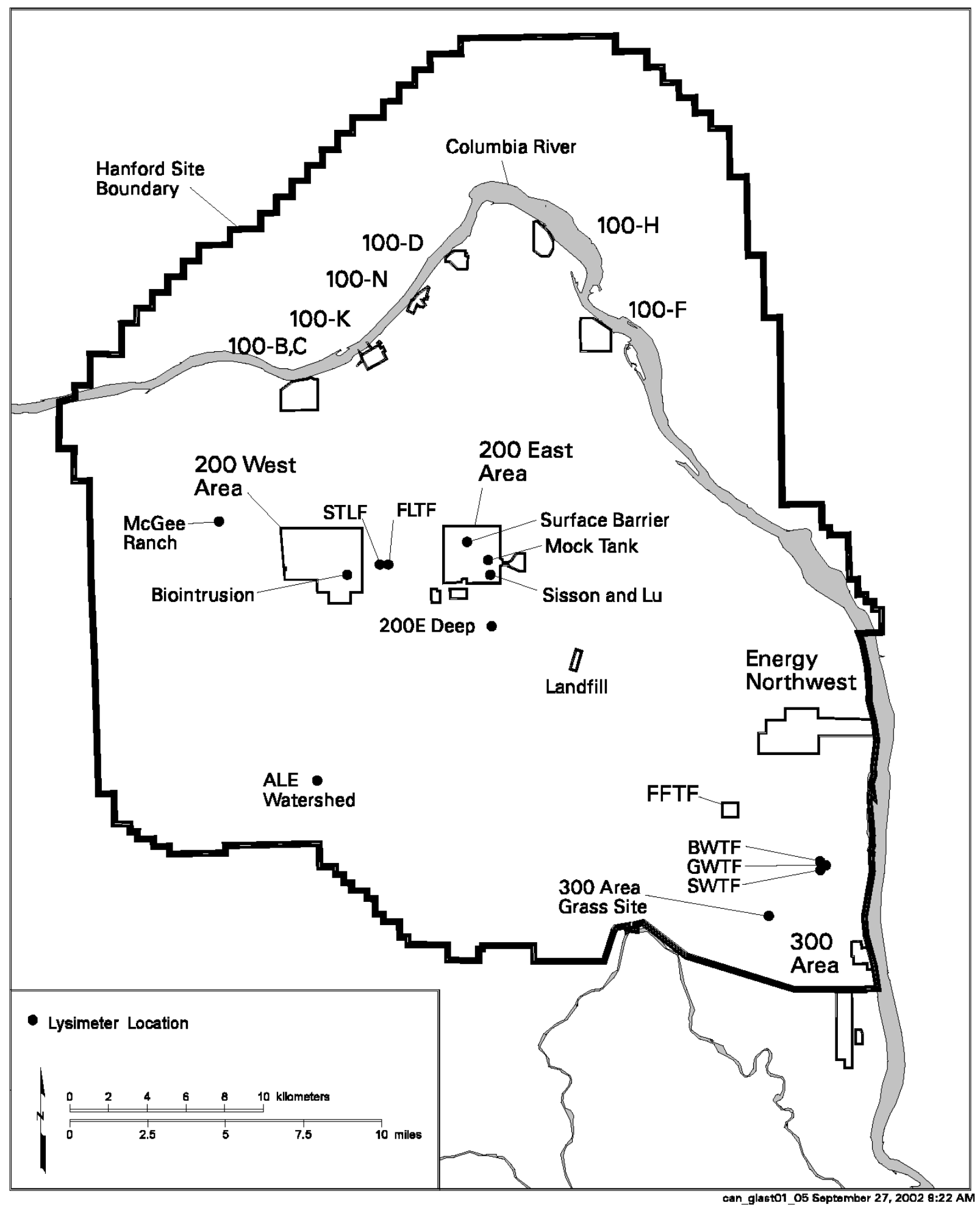

Figure 1. Location of Lysimeters and Other Field Sites at the Hanford Site. 


\subsection{Laboratory Facilities}

Three laboratories have operated on the Hanford Site with the express purpose to support unsaturated hydraulic properties characterization. Prior to the establishment of the earliest soils laboratory at Hanford, a limited number of samples were sent to laboratories offsite. Data from those early laboratory measurements are very limited and procedures are not well documented. Since the bulk of the information being used at Hanford is derived from data provided by onsite laboratories, only the Hanford facilities are discussed here.

\subsubsection{WHC-GEL}

The WHC-GEL data was generated from 1990 through 1995, after which WHC-GEL ceased operations. The procedures that were used to maintain quality control and consistency of laboratory results were contained in the Geotechnical Engineering Procedures Manual (WHC 1986). The types of data collected at the WHC-GEL include water retention curves, sieve analyses, particle and bulk densities, and saturated and unsaturated hydraulic conductivities. Water retention data were collected using Tempe cells, pressure plates, and/or psychrometers. Pressure ranges for the Tempe Cell were 0 to 1,000 centimeters, for the pressure plate 500 to 15,000 centimeters, and for the psychrometer 15,000 to $>1$ million centimeters. Most sieve data is from mechanical sieving; however, there are some hydrometer data also available. The unsaturated hydraulic conductivity was derived by the steady-state head control method. A procedural flaw exists with the water retention data prior to 1993. Before this time, saturated water content measured for the drainage curve was achieved by vacuum saturation of the sample. This does not accurately reflect natural wetting conditions, where some entrapped air would be expected in the field. Consequently, the water retention data prior to 1993 is representative of the primary drying curve rather than the main drying curve. Khaleel and Freeman (1995) revised the pre-1993 water retention curves for the samples listed in their catalog by setting saturated water content equal to the saturated water content measured for the imbibition curves measured for the sediment samples. The raw data from the WHCGEL is available as EXCEL spreadsheet files or in paper form from Eugene Freeman (PNNL), Raz Khaleel (FFS), John Relyea (FH), or Paula Heller (UFA Ventures).

\subsubsection{Pacific Northwest National Laboratory}

The PNNL soil testing laboratory collected hydraulic data from 1977 through the present. Prior to 1977, samples were routinely sent to laboratories offsite to measure hydraulic parameters. The raw data from some of the samples are available in PNNL and site contractor reports only. Detailed records of laboratory analysis by PNNL are not readily available. The apparatus and operational parameters used to collect the PNNL data are similar to those of the WHC-GEL. However, the PNNL soil laboratory did not have a capability to measure unsaturated hydraulic conductivity data until after 1995 . The majority of the analyses done at the PNNL prior to 1995 involved particle size analysis, bulk density, and some measurement of water retention. The procedures that are followed to maintain data quality and consistency are found in the Procedures for Ground-Water Investigations (PNL-6894). Current measurements taken at the soil laboratory include water retention, saturated hydraulic conductivity, unsaturated hydraulic conductivity, particle size distribution, bulk density, particle density, and porosity. Information about the current capabilities at PNNL is available at http://hydrology.pnl.gov/laboratories.asp. 


\subsubsection{Unsaturated Flow Apparatus}

The unsaturated flow apparatus (UFA) is a centrifuge device used to measure the unsaturated hydraulic conductivity of a sediment sample. The advantage that the centrifuge device has over other techniques is that steady-state flow is achieved in a matter of hours rather than days or weeks. One disadvantage of the centrifuge method is that the samples are small sub-cores (about 2 centimeters) that may miss identifying the textural variability in the larger sample. Unsaturated hydraulic conductivity is measured as a function of water content by this method. The centrifuge method does not provide information necessary to generate the moisture retention curve. The centrifuge method has been used at the Hanford Site since 1992. The procedures that are followed to maintain data quality and consistency are found in ASTM D4525 and ASTM D6527-1. A comparison of unsaturated hydraulic conductivity values derived from the centrifuge and from the steady-state head control method is reported by Khaleel et al. (1995). This study notes that the unsaturated hydraulic conductivity at high negative pressures agrees well between the centrifuge method and the steady-state head control method. However, the centrifuge data show an anomalous behavior in the lower negative pressures. The centrifuge method is operated by UFA Ventures, a private testing laboratory located in Richland, Washington. The UFA Ventures' laboratory maintains a website at http://www.ufaventures.com.

As of fiscal year 2001, the WHC-GEL lab is closed; the centrifuge method is not widely used and the PNNL soil laboratory is used only to a limited extent.

\subsection{Lysimeters}

The definition of a lysimeter from the glossary of soil science terms listed on the Soil Science Society of America (SSSA) website is: lysimeter - (i) a device for measuring percolation and leaching losses from a column of soil under controlled conditions. (ii) a device for measuring gains (irrigation, precipitation, and condensation) and losses (evapotranspiration) by a column of soil. Lysimeters at Hanford serve many purposes from water balance studies, drainage and recharge, and waste form performance. Lysimeters are weighing or non-weighing types and their instruments include access tubes to measure water distribution and movement, tensiometers, and thermocouple psychrometers.

\subsubsection{East Area Deep Lysimeter}

The Deep Lysimeter facility is located 4.8 kilometers south of the 200 East Area, about 91.5 meters west of well 699-32-49D. The two lysimeters at the site are 3 meters in diameter and 18 meters deep. One lysimeter is open at the bottom, while the other is closed off with a concrete slab. The lysimeters have instruments with thermocouple psychometers, pressure sensors, and a neutron probe access tube at the center of each lysimeter. The lysimeters, built in 1971, were intended to measure deep percolation through the Hanford Site sediment. The open bottom lysimeter is now destroyed, and the closed bottom lysimeter is currently inactive. These documents provide more information about this site: Brownell et al. (1971), Finlayson (1978), Gee and Heller (1985), Gee and Jones (1985), Hsieh et al. (1973), Isaacson (1982), Last et al. (1976), and Rockhold et al. (1990). 


\subsubsection{Biointrusion Lysimeters}

The Biointrusion Lysimeters facility is located south of the 200 West Area, near the 216-S-10 ditch. There are 28 lysimeters at the site that are 1.2 meters in diameter and 2.4 meters deep. A neutron probe access tube runs through the center of each caisson. The facility, built in 1975, was designed to assess surface barrier design on preventing animal and plant intrusion. This facility has been decommissioned and is no longer available. Further information can be found in Gee and Heller (1985).

\subsubsection{Field Lysimeter Test Facility}

The field lysimeter test facility is located between the 200 East and 200 West Areas, just south of the Hanford Meteorological Station. The facility consists of 14 drainage lysimeters, 2 meters in diameter by 3 meters deep and four weighing lysimeters that are boxes, 1.5 meters on a side and 1.6 meters deep. Instrumentation used at the field lysimeter test facility includes neutron probe, gamma probe, tensiometer, and thermocouple. In addition, there are 6 drainage lysimeters constructed of clear plastic, $0.3 \mathrm{~m}$ in diameter and $3 \mathrm{~m}$ long called "clear-tube lysimeters, that have been used to measure both drainage and visually inspect root growth and water storage changes. The facility, built in 1987, was designed to evaluate protective barrier designs for buried low-level waste disposal facilities. This facility is active and is managed by PNNL. More information about this site is provided in Campbell et al. (1990), Fayer et al. (1999), Gee et al. (1989), Kirkham et al. (1984), Link et al. (1993), and Gee at al. (1992).

\subsubsection{Small Tube Lysimeter Facility}

The small tube lysimeter facility is adjacent to the field lysimeter test facility. There are 105 small tube lysimeters ( 0.3 meter diameter by 1.6 meters deep) that are used to provide replication of the field lysimeter test facility lysimeters and provide alternative treatments. These lysimeters provide water balance measurements for various material and vegetation conditions. This facility is not currently active. Information about this site is located in Gee et al. (1992).

\subsubsection{Vadose Zone Field Site 300N}

The Vadose Zone Field Site, also known as the buried waste test facility (BWTF), is located about 4 $\mathrm{km}$ north of the 300 Area. The facility consists of six non-weighing (7.6 meters deep, two are 2.7 meters in diameter, the other four are 0.6 meter in diameter) and two weighing lysimeters, each a box 1.5 meter on a side and 1.5 meters deep. The bottom ends of the non-weighing lysimeters are capped with a concrete slab and equipped with drainage diversion systems (suction candles). A neutron probe access tube is located at the center of each lysimeter. The facility, built in 1978, was designed to monitor soil storage and drainage in the layered sediment and to monitor radionuclide transport from introduced tracers. This facility is currently active and is managed by PNNL. Information about this site is provided in Cass et al. (1981), Gee and Simmons (1979), Gee and Heller (1985), Jones et al. (1984), Jones and Gee (1984), Rockhold et al. (1988), and Gee et al. (1992). 


\subsubsection{Special Waste Test Facility}

The Special Waste Test Facility is located adjacent to the vadose zone field site 300N (VZFS-300N). The facility consists of 10 lysimeters, each 1.8 meters in diameter by 3 meters deep. The lysimeters are sealed at the bottom with a drainage collection system and porous cup vacuum system. Each caisson has an access tube placed along the outside edge. A 208-liter drum with solidified low-level waste was placed in each caisson. The facility, built in 1983, was designed to monitor leachate rates from buried low-level waste packages. This facility has also been referred to as the commercial waste test facility. This facility is currently inactive and is managed by Bechtel Hanford, Inc. Refer to the following documents for more information: Gee and Heller (1985), Jones et al. (1988), and Jones and Serne (1994, 1995).

\subsubsection{Grout Waste Test Facility}

The Grout Waste Test Facility is located adjacent to the vadose zone field site 300N (VZFS-300N). The facility consists of four lysimeters, each 2 meters in diameter and 8.2 meters deep. The lysimeters were sealed at the bottom and equipped with a porous Teflon vacuum sampler. Each caisson was also equipped with a central, neutron access tube. Fill material within each tube was layered fine and coarse material derived from the AP tank farm. The facility, built in 1985, was designed to measure leachate from grout treated waste. This facility was decommissioned and is no longer available. Additional information is located in Gee and Heller (1985).

\subsubsection{ALE Reserve Lysimeters}

This facility is located along the south-central boundary of the Hanford Site, at the northern end of Rattlesnake Mountain. The facility consists of four weighing lysimeters, each a box 1.5 meters on a side and 1.7 meters deep. The lysimeters are packed with a silt loam soil. The facility, built in 1986, was designed to evaluated soil water storage, drainage, and vegetation cover effects. Additional small weighing lysimeters were used at the ALE reserve to measure evapotranspiration rates, root growth, and contaminant uptake. The small ALE lysimeters are tubes 13 centimeters in diameter by 100 centimeters long with a Lucite plate at the bottom and inserted into the ground. Water content measurements were made after pulling the sampler out of the ground and weighing it. This facility is currently inactive and is managed by PNNL. Information about the ALE lysimeters is in Gee and Heller (1985) and Gee et al. (1992).

\subsubsection{Solid Waste Landfill Basin Lysimeter}

The Solid Waste Landfill Basin Lysimeter was installed in 1991 to monitor environmental impact at the sanitary waste landfill at Hanford. The lysimeter consists of collection basins, sumps, and riser these are used to collect leachate. The landfill is for the disposal of nonradioactive, nonhazardous solid waste. The site is currently active and subject to monitoring. Further information about the facility is available in DynCorp (2000) and Allen et al. (1991). 
Additional information about select lysimeters sites in the list above is available at http://hydrology.pnl.gov/facilities.asp.

\subsection{Other Field Sites}

Other field sites are those sites that are undisturbed, naturally layered sediment or large scale engineered structures that have been instrumented for the purpose of measuring water or contaminant movement in the sediments for a controlled experiment.

\subsubsection{Sisson-Lu Injection Site}

This facility is located near the southwest corner of the Plutonium-Uranium Extraction (PUREX) plant in the 200 East Area and next to trench 216-A-38. This site consists of 32 wells arranged in eight, 1-meter concentric rings, radiating from a central injection well. The 32 monitoring wells are 18 meters deep, while the injection well was 5 meters deep. The monitoring wells are cased with 15.2-centimeterdiameter carbon steel and were used as neutron probe access points. In 1980, eleven water injection events occurred at 1-week intervals. Each injection event lasted about 12 hours and injected about 3,780 liters of water. The moisture distribution was monitored from the 32 observation wells. During the later injections, radionuclide tracers were added. The purpose of the injection experiment was to observe unsaturated flow in Hanford soils and to provide a data set against which to calibrate unsaturated flow models. A description of the original field site layout and analysis of the 1980 injection test is reported by Sisson and $\mathrm{Lu}$ (1984). Fayer et al. (1995) performed a second neutron probe survey at the site and used this new information to re-evaluate the results from the 1980 injection data.

Additional work at the Sisson-Lu site was initiated in fiscal year 2000 and 2001 with the goal of using the existing well field in addition to new data collection techniques at the site to characterize a simulated leak event. Since the work in 1980, the types of tools available for vadose zone characterization of a leak have become more advanced and measure addition indirect properties that relate to soil water content. During fiscal year 2000, nine electrical resistivity tomography arrays were installed, each with 15 electrodes spaced 1 meter apart between 5 to 19 meters deep, four polyvinyl chloride (PVC) access wells were installed, six tensiometer nests were installed by cone penetrometer and three tensiometer nests were installed by auger. In FY 2000, six pulse injection events were performed, with an initial 4,000 liters per week for 5 events in June followed by one additional event in September. The resulting moisture plume was monitored using neutron probe, advance tensiometry, cross borehole radar, crosshole seismic tomography, crosshole electromagnetic induction, high resolution resistivity tomography, and time domain reflectometry. Details of these tests are found in Ward and Gee (2000), Ward and Gee (2001) and Gee and Ward (2001). Investigator summary reports are available at http://vadose.pnl.gov.

\subsubsection{Mock Tank Facility}

The Mock Tank Facility is a one-quarter scale model of a high-level waste tank located in the central 200 East Area separations site. The purpose of the site is to simulate a leak and permit monitoring of the leak event under the same physical setting that is expected for an actual waste tank. A series of electrical resistivity tomography (ERT) vertical electrode arrays (VEA) were placed around the mock tank using a 
cone penetrometer (CPT). Once the array was installed, a leak at the mock tank was initiated and the plume progress was monitored by the ERT system. A description of the 1992 leak test is available in Narbutovskih et al. (1996, p. 55) and Ramirez et al. (1996. p. 108). Recent work focused on leak detection mitigation and monitoring (LDMM) has been reported by Barnett et al. 2002.

\subsubsection{Prototype Surface Barrier Facility}

The Prototype Surface Barrier Facility is a field scale surface barrier designed to limit recharge and biointrusion at buried waste sites. The facility covers an area 2.4 hectares in the 200 East Area near the 200-BP-1 site and is instrumented with neutron probe access ports, time-domain reflectometry, and tensiometers. The facility was built in 1994 and has been subjected to numerous infiltration tests since that time. Data from this site has been used to estimate surface barrier performance at the Hanford Site for periods up to 1000 years. This is based on water stresses imposed via irrigation and record precipitation events during the past 8 years. The data from this site show that evapotranspiration (ET) is effective in removing all of the incident surface water under both ambient and irrigated (e.g., three times the annual average) conditions. The data support the concept that surface barrier can be highly effective in minimizing drainage at buried waste sites at Hanford. Additional information about the prototype surface barrier is available in Ward and Gee $(1997,2000)$ and Link et al. (1995).

\subsubsection{Area Grass Site}

The grass site is located on flat terrain southeast of the Fast-Flux Test Facility. Vegetation cover over the site consists of Sandberg's bluegrass and cheatgrass. Twenty-five neutron probe access tubes were installed in a 5 by 5 grid with a 6-meter separation between tubes. Each tube was completed to a depth of 3.5 meters. The purpose of the site is to quantify year-to-year natural recharge beneath a grass, covered sand typical of the Hanford Site. The grass site was established in 1983. Additional information about the grass site can be found in Fayer and Walters (1995), Rockhold et al. (1990), and Rockhold et al. (1988).

\subsection{Bibliography}

The bibliography found in Appendix B represents a partial list of documents that contain information about the soil physics properties of the sediment at the Hanford Site. There are other publications that are more focused on the geochemistry and geology included in the companion documents (Horton et al., 2001) to this report on soil physics data. Many of the reports from the companion documents are not included here but are left to the authors of the other reports for inclusion. This list is not intended to incorporate all publications in each category that are available. There is also some redundancy with previous and companion bibliographic catalogs. The list of publications is intended to highlight many of the important reports that are most relevant to the soil physics objectives. Many more publications that are not in the reference list can be found in the reference lists of the referenced material. There are also many sources of data that do not have a reference, but are located in letter reports and personal logs. 
Many of these letter reports and personal logs are lost or in the possession of the original authors, and therefore not available.

\subsection{Conclusions}

The number of publications containing information about unsaturated hydraulic properties has steadily grown since the first reports in the late 1950s and early 1960s. The number of laboratory measurements increased dramatically in the 1990s with the startup of WHC-GEL and introduction of UFA. The lysimeters facilities onsite were built during the 1970s and 1980s. Currently, the majority of the lysimeters are inactive or decommissioned. The number of laboratory samples processed has also decreased since WHC-GEL closed. Current activities at the Sisson-Lu site, prototype barrier, and mock tank are focused on quantifying larger scale properties of the sediment, such as the effects spatial heterogeneity has on fluid flow. Despite the slowdown of some data collection activities, a large quantity of data has been collected and is available to improve our understanding of the flow dynamics of the Hanford Site. The data sources have been fragmented among different contractors and are in documents that are not cataloged, nor readily available. This report is an attempt to identify some of the available Hanford relevant data and literature. For the purpose of locating material, reports can be grouped into three categories:

- PNNL and Bechtel Hanford, Inc. (BHI) reports

- contractor reports

- raw data/laboratory records.

The PNNL and BHI reports are available at the Hanford Public Reading Room at the Technical Library on the Washington State University, Tri-Cities campus. The current and historical contractor reports are available at Central Files (509-376-5440). Contractor reports cannot be checked out, but reproductions can be made upon request. Laboratory/raw data are not maintained in a central location. Data is often only available from individuals or documented in reports. As part of this continuing effort, it would be useful to develop an electronic index of Hanford publications that can be searched through the use of a keyword/subject.

Sources of raw data from sites were identified and cataloged as part of the effort for this project. The number of sample sets from six designated areas at Hanford (100, 200 East, 200 West, 300, 400, and 600) and for 10 measurement methods are summarized in Table 1. Columns 2 through 6 in Table 1 represent hydraulic properties data derived from laboratory methods. For these data, each discrete sample is counted as one occurrence. Column 7 represents measurements taken at neutron probe field sites. A more detailed listing of the samples and site locations are listed in Appendix C.

The number of boreholes for which data are available is listed in Appendix C. For each borehole, there could be data from multiple depth intervals and many measurements taken at multiple time intervals. The number of boreholes does not reflect the total number of neutron probe measurements. 
A more thorough coverage of neutron probe measurements can be found in Last and Horton (2000). The lysimeter facilities are not included among the neutron count data. The number listed in columns 8 through 10 refers to the number of lysimeters or other sites where storage, drainage, or moisture profile

Table 1. Data Types and Areas

\begin{tabular}{||l|c|c|c|c|c|c|c|c|c|c||}
\hline \multicolumn{1}{|c|}{ Area } & Sieve & Density & Moisture & $\begin{array}{c}\text { Unsat. } \\
\text { Cond. }\end{array}$ & $\begin{array}{c}\text { Sat. } \\
\text { Cond. }\end{array}$ & Neutron & Storage & Drainage & $\begin{array}{c}\text { Water } \\
\text { Profile }\end{array}$ & $\begin{array}{c}\text { Air } \\
\text { Permeability }\end{array}$ \\
\hline \hline 100 & 84 & 84 & 84 & 33 & 33 & -- & -- & -- & -- & -- \\
\hline 200 East & 122 & 125 & 108 & 63 & 46 & 36 & -- & 2 & -- & 1 \\
\hline 200 West & 163 & 124 & 60 & 89 & 29 & -- & 1 & 3 & 1 & 1 \\
\hline 300 & -- & -- & 2 & -- & -- & -- & 1 & 1 & 1 & -- \\
\hline 400 & -- & -- & -- & -- & -- & -- & -- & 1 & 1 & -- \\
\hline 600 & 117 & 168 & 149 & 49 & 46 & -- & 8 & 9 & 8 & -- \\
\hline
\end{tabular}

data, respectively, is collected. Two sites in Appendix $\mathrm{C}$ have a discrete number in the cell representing drainage. This signifies an infiltrometer test result and the number represents the number of tests. The last column indicates that in-situ, borehole air permeability measurements were made at two sites. This number does not reflect the number of times a measurement was made for each borehole.

\subsection{References}

Allen R.G., T.A. Howell, W.O. Pruitt, I.A. Walter, and M.E. Jensen. 1991. "Lysimeter for Evapotranspiration and Environmental Measurements." In Proceedings of the International Symposium on Lysimetry, American Society of Civil Engineers, Honolulu, Hawaii, pp. 397-403.

ASTM. 1990. Standard Method for Permeability of Rocks by Flowing Air. ASTM D4525, American Society for Testing and Materials, New York.

ASTM. 2000. Test Method for Determining Unsaturated and Saturated Hydraulic Conductivity in Porous Media by Steady-State Centrifugation. ASTM D6527-1, American Society for Testing and Materials, New York.

Brownell, L.E., R.E. Isaacson, J.P. Sloughter, and M.D. Veatch. 1971. Moisture Movement in Soils on the Hanford Reservation. ARH-2068, Atlantic Richfield Hanford Company, Richland, Washington.

DeLamare, M.A. 2000. Groundwater/Vadose Zone Integration Project Systems Engineering Management Plan. BHI-01347, Rev. 0, Bechtel Hanford, Inc., Richland, Washington. 
DynCorp. 2000. Hanford Solid Waste Landfill Closure Plan. HNF-7173 Rev. 0, DynCorp Tri-Cities Services, Inc., Richland, Washington.

Fayer, M.J. and T.B. Walters. 1995. Estimated Recharge Rates at the Hanford Site. PNL-10285, Pacific Northwest Laboratory, Richland, Washington.

Fayer, M.J., R.E. Lewis, R.E. Engelman, A.L. Pearson, C.J. Murray, J.L. Smoot, R.R. Randall, W.H. Wegener, and A.H. Lu. 1995. Re-Evaluation of a Subsurface Injection Experiment for Testing Flow and Transport Models. PNL-10860, Pacific Northwest Laboratory, Richland, Washington.

Finlayson, B.A., R.W. Nelson, and R.G. Baca. 1978. A Preliminary Investigation into the Theory and Techniques of Modeling Natural Moisture Movement in Unsaturated Sediments. RHO-LD-47, Rockwell Hanford Operations, Richland, Washington.

Gee, G.W. and P.R. Heller. 1985. Unsaturated Water Flow at the Hanford Site: Review of Literature and Annotated Bibliography. PNL-5428, Pacific Northwest Laboratory, Richland, Washington.

Gee, G.W. and T.L. Jones. 1985. Lysimeters at the Hanford Site: Present Use and Future Needs. PNL-5578, Pacific Northwest Laboratory, Richland, Washington.

Gee, G.W., M.J. Fayer, M.L. Rockhold, and M.D. Campbell. 1992. "Variation in Recharge at the Hanford Site." Northwest Sci. 66:237-250.

Gee G.W. and A.L. Ward, 2001, Vadose Zone Transport Field Study: Status Report. PNNL-13679, Pacific Northwest National Laboratory. Richland, Washington.

Hsieh, J.J.C., A.E. Reisenauer, and L.E. Brownell. 1973. A Study of Soil Matric Potential and Temperature in Hanford Soils. BNWL-1712, Battelle, Pacific Northwest Laboratory, Richland, Washington.

Isaacson, R.E. 1982. Supporting Information for the Scientific Basis for Establishing Dry Well Monitoring Frequencies. RHO-RE-EV-4-P, Rockwell Hanford Operations, Richland, Washington.

Khaleel, R. and E.J. Freeman. 1995. Variability and Scaling of Hydraulic Properties for 200 Area Soils, Hanford Site. WHC-EP-0883, Westinghouse Hanford Company, Richland, Washington.

Khaleel, R., J.F. Relyea, and J.L. Conca. 1995. "Evaluation of van Genuchten-Mualem Relationships to Estimate Unsaturated Hydraulic Conductivity at Lower Water Content." Water Resour. Res., 31(11):2659-2668.

Klute, A. 1986. Methods of Soil Analysis, Part 1, $2^{\text {nd }}$ ed., American Society of Agronomy, Madison, Wisconsin. 
Last, G.V. and D.G. Horton. 2000. Review of Geophysical Characterization Methods Used at the Hanford Site. PNNL-13149, Pacific Northwest National Laboratory, Richland, Washington.

Last, G.V., P.G. Easley, and D.J. Brown. 1976. Soil Moisture Transport During the 1974-1975 and 1975-1976 Water Years. ARH-ST-146, Atlantic Richfield Hanford, Richland, Washington.

Link, S.O., R.N. Kickert, M.J. Fayer, and G.W. Gee. 1993. A Comparison of Simulation Models for Predicting Soil Water Dynamics in Bare and Vegetated Lysimeters. PNL-8675, Pacific Northwest Laboratory, Richland, Washington.

Narbutovskih, S.M., D.F. Iwatate, M.D. Sweeney, A.L. Ramirez, W. Daily, R.M. Morey, and L. Christensen. 1996. Feasibility of CPT-Deployed Vertical Electrode Array in Single Shell Tank Farms. WHC-SD-EN-TA-004, Westinghouse Hanford Company, Richland, Washington.

PNL. 1992. Procedures for Ground-Water Investigations. PNL-6894, Rev. 1, Pacific Northwest Laboratory, Richland, Washington.

Ramirez, A., W. Daily, A. Binley, D. LaBrecque, and D. Roelant. 1996. "Detection of Leaks in Underground Storage Tanks Using Electrical Resistance Methods." Journal of Environ. and Eng. Geoph., 1(3):189-203.

Rockhold, M.L., M.J. Fayer, and G.W. Gee. 1988. Characterization of Unsaturated Hydraulic Conductivity at the Hanford Site. PNL-6488, Pacific Northwest Laboratory, Richland, Washington.

Rockhold, M.L., M.J. Fayer, G.W. Gee, and M.J. Kanyid. 1990. Natural Groundwater Recharge and Water Balance at the Hanford Site. PNL-7215, Pacific Northwest Laboratory, Richland, Washington.

Sisson, J.B. and A.H. Lu. 1984. Field Calibration of Computer Models for Application to Buried Liquid Discharges: A Status Report. RHO-ST-46, Rockwell Hanford Operations, Richland, Washington.

Ward, A.L. and G.W. Gee. 1997. "Performance and Water Balance Evaluation of a Field-Scale Surface Barrier." Journal Environ. Qual. 26:694-705.

Ward A.L. and G.W. Gee, 2000, Vadose Zone Transport Field Study: Detailed Test Plan for Simulated Leak Tests. PNNL-13263, Pacific Northwest National Laboratory. Richland, Washington.

Ward, A.L. and G.W. Gee, 2001, Vadose Zone Transport Field Study: FY 2001 Test Plan. PNNL-13451, Pacific Northwest National Laboratory. Richland, Washington.

Westinghouse Hanford Company. 1986. Geotechnical Engineering Procedures Manual. WHC-IP-0635, Westinghouse Hanford Company, Richland, Washington. 
Gee, G. W. 1987. Recharge at the Hanford Site: Status Report. PNL-6403, Pacific Northwest Laboratory, Richland, Washington.

Gee, G. W., and D. Hillel. 1988. "Groundwater Recharge in Arid Regions: Review and Critique of Estimation Methods.” J. Hydrol. Process. 2:255-266

Gee, G.W. and P.R. Heller. 1985. Unsaturated Water Flow at the Hanford Site: Review of Literature and Annotated Bibliography. PNL-5428, Pacific Northwest Laboratory, Richland, Washington.

Gee, G.W. and T.L. Jones. 1985. Lysimeters at the Hanford Site: Present Use and Future Needs. PNL-5578, Pacific Northwest Laboratory, Richland, Washington.

Gee, G. W. and D. Or. 2002. "Particle-size analysis". In Ch 2. Methods of Soil Analysis, Part 1. J. Dane and C. Topp (eds.). Soil Sci. Soc. Am., Madison, Wisconsin ( in press-Sept. 2002).

Gee G.W. and A.L. Ward, 2001, Vadose Zone Transport Field Study: Status Report. PNNL-13679, Pacific Northwest National Laboratory. Richland, Washington.

Gee, G. W., and A. L. Ward. 2002. Predicting deep drainage using soil hydraulic properties and soil texture data. 9 pp. In Transaction of the $17^{\text {th }}$ World Congress of Soil Science. Bangkok, Thailand, August 2002 (electronic).

Gee, G. W. and A. L. Ward. 2002. Vadose Zone Field Experiments and Recharge Estimates for the SSX Tank Farm. Appendix D.8 - S-SX Tank Farm Field Investigation Report.

Gee, G. W. and A. L. Ward. 2002. "Vapor transport in dry soils". Encyclopedia of Water Science, Marcel Dekker (in press)

Gee, G. W., C. T. Kincaid, R. J. Lenhard, and C. S. Simmons. 1991. "Recent Studies of Flow and Transport in the Vadose Zone." Rev. Geophys. 29 (2):227-239.

Gee, G.W., M.J. Fayer, M.L. Rockhold, and M.D. Campbell. 1992. "Variation in Recharge at the Hanford Site." Northwest Sci. 66:237-250.

Gee, G. W., L. L. Cadwell, H. D. Freeman, M. W. Ligotke, S. O. Link, R. A. Romine, and W. H. Walters, Jr. 1993. Testing and Monitoring Plan for the Permanent Isolation Surface Barrier Prototype. PNL8391, Pacific Northwest Laboratory, Richland, Washington.

Gee, G. W., D. Felmy, J. C. Ritter, M. D. Campbell, J. L. Downs, M. J. Fayer, R. R. Kirkham, and S. O. Link. 1993. Field Lysimeter Test Facility: Status Report IV: FY 1993. PNL-8911, Pacific Northwest Laboratory, Richland, Washington.

Gee G.W., A.L. Ward, B.G. Gilmore, M.W. Ligotke, and S.O. Link. 1995. Hanford Prototype-Barrier Status Report: FY 1995. PNL-10872, Pacific Northwest Laboratory. Richland, Washington. 
Gee, G. W., A. L. Ward, B. G. Gilmore, M. W. Ligotke, and S. O. Link. 1995. Hanford Prototype Surface Barrier Status Report: FY 1995. PNL-10872, Pacific Northwest Laboratory, Richland, Washington.

Gee, G. W., A. L. Ward, B. G. Gilmore, S. O. Link, G. W. Dennis, and T. K. O'Neil. 1996. Hanford Prototype Barrier Status Report: FY 1996. PNL 11367, Pacific Northwest National Laboratory, Richland, Washington.

Gee G.W., A.L. Ward, B.G. Gilmore, S.O. Link, G.W. Dennis, and T.K. O’Neil. 1996. Hanford Prototype-Barrier Status Report: FY 1996. PNNL-11367, Pacific Northwest National Laboratory. Richland, Washington.

Gee G.W. and A.L. Ward. 1997. "Still in Quest for the Perfect Cap.” P. 145-164. In T.D. Reynolds and R.C. Morris (eds). Landfill Capping in the Semi-Arid West, Conference Proceedings. Jackson Lake, Wyoming. May 1997, Environmental Science and Research Foundation, Idaho Falls, Idaho.

Gee G.W., A.L. Ward, and M.J. Fayer. 1997. "Surface Barrier Research at the Hanford Site.” Land Contamination and Reclamation. 5(3):233-237.

Gee G.W., N.R. Wing, and A.L. Ward. 1997. "Development and Testing of Permanent Isolation Surface Barriers at the Hanford Site." p. D3-D22. In Barrier Technologies for Environmental Management. National Academy Press, Washington. D.C.

Gee G.W. and A.L. Ward. 2001. Vadose Zone Transport Field Study: Status Report. PNNL-13679, Pacific Northwest National Laboratory, Richland, Washington.

Gee, GW, AL Ward, JC Ritter, JB Sisson, JM Hubbell, H Sydnor. 2001. Installation of a Hydrologic Characterization Network for Vadose Zone Monitoring of a Single-Shell Tank Farm at the U. S. Department of Energy Hanford Site. PNNL-13712, Pacific Northwest National Laboratory, Richland, Washington.

Gee, G. W., A. L. Ward, T. G. Caldwell, and J. C. Ritter. 2002. “A vadose-zone water flux meter with divergence control’. Water Resour. Res.38 (8); 10.1029/2001WR00816, 2002.

Gee, G. W., A. L. Ward, Z. F. Zhang, G. S. Campbell, and J. Mathison. 2002. “ The influence of hydraulic non-equilibrium on pressure plate data.”. Vadose Zone J. 1:172-178

Horton, D. G., G. V. Last, T. J Gilmore, and B. N Bjornstad. September 2001. A Catalog of Geologic Data for the Hanford Site. PNNL-13653. Pacific Northwest National Laboratory, Richland, Washington.

Hsieh, J.J.C., A.E. Reisenauer, and L.E. Brownell. 1973. A Study of Soil Matric Potential and Temperature in Hanford Soils. BNWL-1712, Battelle, Pacific Northwest Laboratory, Richland, Washington. 
Hunt A.G. 2001. "Application of Percolation Theory to Porous Media with Distributed Local Conductances." Adv. Water Resour. 24:279-307.

Hunt A.G and G.W. Gee. 2002. "Application of Critical Path Analysis to Fractal Porous Media: Comparison with Examples from the Hanford Site.” Adv. Water Resour. 25(1):129-146.

Hunt, A. G., and G. W. Gee. 2002. "Water-retention estimates using continuum percolation theory: Test of Hanford Site soils". Vadose Zone J. (in press-Nov. issue).

Isaacson, R.E. 1982. Supporting Information for the Scientific Basis for Establishing Dry Well Monitoring Frequencies. RHO-RE-EV-4-P, Rockwell Hanford Operations, Richland, Washington.

Jones, T. L, G. W. Gee, R. R. Kirkham, and D. D. Gibson. 1982. The Measurement of Water Potential in Low-Level Waste Management. PNL-4388, Pacific Northwest Laboratory, Richland, Washington.

Jones T.L. and R.J. Serne. 1994. Special Waste Form Lysimeter-Arid 1984-1992 Data Summary and Preliminary Interpretation. PNL-8955, Pacific Northwest Laboratory, Richland, Washington.

Jone, T. L, and R. J. Serne. 1995. "Contaminant release from solidified radioactive waste buried in unsaturated sediments: Lysimeter study”. J. Environ. Qual. 24:1063-1073

Khaleel, R. and E.J. Freeman. 1995. Variability and Scaling of Hydraulic Properties for 200 Area Soils, Hanford Site. WHC-EP-0883, Westinghouse Hanford Company, Richland, Washington.

Khaleel, R., J.F. Relyea, and J.L. Conca. 1995. "Evaluation of van Genuchten-Mualem Relationships to Estimate Unsaturated Hydraulic Conductivity at Lower Water Content." Water Resour. Res., 31(11):2659-2668.

Klute, A. 1986. Methods of Soil Analysis, Part 1, $2^{\text {nd }}$ ed., American Society of Agronomy, Madison, Wisconsin.

Last G.V. and T.D. Caldwell. 2001. Core Sampling in Support of the Vadose Zone Transport Field Study. PNNL-13454, Pacific Northwest National Laboratory, Richland, Washington.

Last, G.V. and D.G. Horton. 2000. Review of Geophysical Characterization Methods Used at the Hanford Site. PNNL-13149, Pacific Northwest National Laboratory, Richland, Washington.

Last, G.V., P.G. Easley, and D.J. Brown. 1976. Soil Moisture Transport During the 1974-1975 and 1975-1976 Water Years. ARH-ST-146, Atlantic Richfield Hanford, Richland, Washington.

Last G.V., T.D. Caldwell, and A.T. Owen. 2001. Sampling of Boreholes WL-3A through -12 in Support of the Vadose Zone Transport Field Study. PNNL-13631, Pacific Northwest National Laboratory. Richland, Washington. 
Link, S.O., R.N. Kickert, M.J. Fayer, and G.W. Gee. 1993. A Comparison of Simulation Models for Predicting Soil Water Dynamics in Bare and Vegetated Lysimeters. PNL-8675, Pacific Northwest Laboratory, Richland, Washington.

Link, S. O., L. L. Cadwell, C. A. Brandt, J. L. Downs, R. E. Rossi, and G. W. Gee. 1994. Biointrusion Test Plan for the Permanent Isolation Surface Barrier Prototype. PNL-9411, Pacific Northwest Laboratory, Richland, Washington.

Link S.O., N.R. Wing, and G.W. Gee. 1995. The Development of Permanent Isolation Barriers for Buried Wastes in Cold Deserts: Hanford Washington." J. Arid Lands Studies 4:215-224.

Meyer P. D., M. L. Rockhold, W. E. Nichols, and G. W. Gee. 1996. Hydrologic Evaluation Methodology for Estimating Water Movement through the Unsaturated Zone at Commercial Low-Level Radioactive Waste Disposal Sites. NUREG/CR-6346, U. S. Nuclear Regulatory Commission, Washington, D. C.

Myers, D.R. 1985. Diposal Materials Study. RHO-WM-EV-12-P, Rockwell Hanford Operations, Richland, Washington.

Narbutovskih, S.M., D.F. Iwatate, M.D. Sweeney, A.L. Ramirez, W. Daily, R.M. Morey, and L. Christensen. 1996. Feasibility of CPT-Deployed Vertical Electrode Array in Single Shell Tank Farms. WHC-SD-EN-TA-004, Westinghouse Hanford Company, Richland, Washington.

Petersen, K. L., S. O. Link, and G. W. Gee (eds.). 1995. Hanford Site Long-Term Surface Barrier Development Program: Fiscal Year 1994 Highlights. PNL 10605, Pacific Northwest Laboratory, Richland, Washington.

PNL. 1992. Procedures for Ground-Water Investigations. PNL-6894, Rev. 1, Pacific Northwest Laboratory, Richland, Washington.

Ramirez, A., W. Daily, A. Binley, D. LaBrecque, and D. Roelant. 1996. "Detection of Leaks in Underground Storage Tanks Using Electrical Resistance Methods." Journal of Environ. and Eng. Geoph., 1(3):189-203.

Rockhold, M.L., M.J. Fayer, and G.W. Gee. 1988. Characterization of Unsaturated Hydraulic Conductivity at the Hanford Site. PNL-6488, Pacific Northwest Laboratory, Richland, Washington.

Rockhold, M.L., M.J. Fayer, G.W. Gee, and M.J. Kanyid. 1990. Natural Groundwater Recharge and Water Balance at the Hanford Site. PNL-7215, Pacific Northwest Laboratory, Richland, Washington.

Sackschewsky M.R., C.J. Kemp, S.O. Link, and W.J. Waugh. 1995. "Soil Water Balance Changes in Engineered Soil Surfaces.” J. Environ. Qual. 24:352-359. 
Serne, R. J., H. T. Schaef, B. N. Bjornstad, D. C. Lanigan, G. W. Gee, C. W. Lindenmeier, R. E. Clayton, V.L. LeGore, R. D. Orr, M. J. O’Hara, C. F. Brown, G. V. Last, D. S. Burke, T. C. Wilson, and B. A. Williams. 2002. Characterization of Vadose Zone Sediment: Borehole 299-W23-19 [SX-115] in the SSX Waste Management Area: PNNL-13757-2 (electronic). Pacific Northwest National Laboratory, Richland, Washington.

Sisson, J.B. and A.H. Lu. 1984. Field Calibration of Computer Models for Application to Buried Liquid Discharges: A Status Report. RHO-ST-46, Rockwell Hanford Operations, Richland, Washington.

Sisson, J. B., G. W. Gee, J. M. Hubbell, W. L. Bratton, J. C. Ritter, A. L. Ward, and T. G. Caldwell. 2002. "Advances in tensiometry for long-term monitoring of capillary pressures". Vadose Zone J. (in press-Nov. issue).

Smyth, J. D., E. Bresler, G. W. Gee, and C. T. Kincaid. 1990. Development of an Infiltration Evaluation Methodology for Low-Level Waste Shallow Land Burial Sites. NUREG/CR-5523, U.S. Nuclear Regulatory Commission, Washington, D.C.

U.S. Department of Energy. 1999. 200-BP-1 Prototype Barrier Treatability Test Report. DOE/RL-99-11. U.S. Department of Energy, Richland, Washington.

Walter, M. B., M. J. Graham, and G. W. Gee. 1984. A Field Lysimeter Facility for Evaluating the Performance of Commercial Solidified Low-Level Waste. PNL-5253, Pacific Northwest Laboratory, Richland, Washington.

Ward, A.L. and G.W. Gee. 1997. "Performance and Water Balance Evaluation of a Field-Scale Surface Barrier." Journal Environ. Qual. 26:694-705.

Ward, A. L., and G. W. Gee. 2000. "Hanford Site Surface Barrier Technology." In Vadose Zone Science Technology and Solutions, pp. 1414-1423. U. S. Department of Energy, Battelle Press, Columbus, Ohio.

Ward A.L. and G.W. Gee. 2000. Vadose Zone Transport Field Study: Detailed Test Plan for Simulated Leak Tests. PNNL-13263, Pacific Northwest National Laboratory, Richland, Washington.

Ward A.L. and G.W. Gee. 2001. Vadose Zone Transport Field Study: FY 2001 Test Plan. PNNL-13451, Pacific Northwest National Laboratory, Richland, Washington.

Ward A.L. and G.W. Gee. 2001. Vadose Zone Transport Field Study: FY 2002 Test Plan. PNNL-13587. Pacific Northwest National Laboratory, Richland Washington.

Ward A.L., G.W. Gee, and S.O. Link. 1997. Hanford Prototype-Barrier Status Report: FY 1997. PNNL11789. Pacific Northwest National Laboratory. Richland, Washington.

Ward, A. L., G. W. Gee, and M. D. White. 1997. A Comprehensive Analysis of Contaminant Transport in the Vadose Zone Beneath Tank SX-109. PNNL-11463, Pacific Northwest National Laboratory, Richland, Washington. 
Ward, A. L., and G. W. Gee. 2000. Hanford site surface barrier technology. p. 1415-1423. In B.B. Looney, and R. W. Falta (eds.). Vadose Zone Science and Technology Solutions. Battelle Press, Columbus, Ohio.

Westinghouse Hanford Company. 1986. Geotechnical Engineering Procedures Manual. WHC-IP-0635, Westinghouse Hanford Company, Richland, Washington.

Wierenga, P. J., M. H. Young, G. W. Gee, R. G. Hills, C. T. Kincaid, T. J. Nicholson, and R. E. Cady. 1993. Soil Characterization Methods for Unsaturated Low-Level Waste Sites. NUREG/CR-5988, U.S. Nuclear Regulatory Commission, Washington D.C.

Wing, N. R., and G. W. Gee (eds). 1990. Hanford Site Protective Barrier Development Program. Fiscal Year 1989 Highlights. WHC-EP-0318, Westinghouse Hanford Company, Richland, Washington.

Wing N.R., F.M. Corpuz, K.L. Peterson, and A.M. Tallman. 1995. Physical Stability of Long-Term Surface Barriers-Assessment of Potentially Disruptive Events. BHI-00145, Bechtel Hanford Inc., Richland, Washington.

Wing N.R., K.L. Petersen, C. Whitlock, and R.L. Burk. 1995. Long-Term Climate Change Effects Task for the Hanford Permanent Isolation Barrier Development Program: Final Report. BHI-00144. Bechtel Hanford Inc. Richland, Washington.

Wittreich C.D. and C.R. Wilson. 1991. "Lysimeters for Evapotransiration and Environmental Measurements.” Proceedings from the International Symposium of Lysimetry. American Society of Civil Engineers, Honolulu, Hawaii.

Zhang, Z. F., A. L. Ward and G. W. Gee. 2002. A Parameter Scaling Concept for Estimating Field-Scale Hydraulic Functions of Layered Soils pp. 103-107. In A. N Findkakis (ed.) Proceedings of the 2002 International Groundwater Symposium, Lawrence Berkeley National Laboratory, Berkeley, California, March 2002.

Zhang, Z. F., A. L. Ward, and G. W. Gee. 2002. Estimating soil hydraulic parameters of a field drainage experiment using inverse techniques. Vadose Zone J. (in press- Nov. issue) 


\section{Appendix A}

\section{Parameter Characteristics and Related References}




\section{Appendix A}

\section{Parameter Characteristics and Related References}

This appendix lists characteristics of the data found in publications in the bibliography (Appendix B). The format used in this appendix was duplicated from that used by Gee and Heller (1985) in the previous bibliography. The numbers next to each category correspond to the reference number listed in Appendix B and Appendix D. 
Table A.1. Unsaturated Zone Characteristics Identified in Published Reports for Hanford Sites

\begin{tabular}{|c|c|c|}
\hline Characteristic & Reference & \\
\hline \multicolumn{3}{|l|}{ Water Content } \\
\hline Laboratory & $2,3,7,11,12,13,23,26,28,29,33,34,39,40,41,42,43,51,52,53,54,55,62,65,70,76$ & $77,79,81,86,87,92,99$ \\
\hline Neutron Probe & $4,5,6,19,20,27,37,42,43,44,45,46,47,48,49,50,57,61,65,66,80,91,96$ & \\
\hline \multicolumn{3}{|l|}{ Water Potential } \\
\hline Psychrometer & $4,5,6,15,39,42,43,47,49$ & \\
\hline Block & $43,47,49$ & \\
\hline Tensiometer & $6,7,22,66,96$ & \\
\hline Pressure Plate & 7,89 & \\
\hline \multicolumn{3}{|l|}{ Hydraulic Conductivity } \\
\hline Saturated & $2,3,7,11,12,13,28,29,34,51,54,55,81,86,87,99$ & \\
\hline Unsaturated & $8,9,10,23,29,52,55,77,79,81,86,87,90,102$ & \\
\hline Air Permeability & $67,72,86,87,88$ & \\
\hline \multicolumn{3}{|l|}{ Texture } \\
\hline Particle Size Distribution & $8,9,10,11,12,13,23,26,33,34,40,41,42,51,62,68,79,81,86,87,90,92,94,99,102$ & \\
\hline \multicolumn{3}{|l|}{ Water Balance } \\
\hline Soil Water Storage & $4,5,6,20,22,30,33,37,44,46,47,48,50,57,61,66,80,96$ & \\
\hline Soil Water Drainage & $5,6,14,22,27,30,33,34,42,47,49,50,57,66,80,96$ & \\
\hline Soil Water Profile & $6,20,22,27,34,37,65,96$ & \\
\hline \multicolumn{3}{|l|}{ Temperature } \\
\hline Thermal Conductivity & $7,25,27$ & \\
\hline Thermal Profile & $5,22,27,42,44,49,61$ & \\
\hline \multicolumn{3}{|l|}{ Spatial Variability } \\
\hline Water Content & $19,39,89,91$ & \\
\hline Hydraulic Conductivity & 39 & \\
\hline Model Simulation & $25,27,30,47,48,57,77,91,92,17,82,85$ & \\
\hline
\end{tabular}




\section{Appendix B}

Bibliography of Vadose Zone Hydraulic Properties for the Hanford Site 


\section{Appendix B}

\section{Bibliography of Vadose Zone Hydraulic Properties for the Hanford Site}

The references in this appendix are arranged in alphabetical order of the first author and then arranged by date of publication. There are 160 documents listed in this reference list that contain soil physics properties data of Hanford sediments. This list is not an all-encompassing list of all the work that has been done at Hanford, but rather is intended to provide a list of important documents used in the characterization of unsaturated properties of the Hanford sediments. The number before each reference is the index and corresponds to the numbers in Appendix A and Appendix D. 
1. Allen R.G., T.A. Howell, W.O. Pruitt, I.A. Walter, and M.E. Jensen. 1991. "Lysimeter for evapotranspiration and Environmental Measurements." In Proceedings of the International Symposium on Lysimetry, American Society of Civil Engineers, Honolulu, Hawaii, pp. 397-403.

2. Bergeron M.P., G.V. Last, and A.E. Reisenauer. 1987. Geohydrology of a Commercial Low-Level Radioactivity Waste Disposal Facility Near Richland, Washington. PNWD-1127, Richland, Washington.

This report summarizes the geohydrologic conditions that exist beneath the U.S. Ecology waste disposal site, south of the 200 East Area. The U.S. Ecology site has operated since 1965. The sediment beneath the site, in ascending order, is the Middle member of the Ringold Formation, Hanford sands, and eolian sands at the surface. The water table at Middle Ringold Formation rises about 5.2 meters above the water table, the Hanford formation is about 91.5 meters thick and the eolian sands form a thin veneer on the surface. Flow properties through the vadose zone are derived by fitting a curve through water retention data and the saturated hydraulic conductivity for samples collected at the site. There are also particle size curves for the site samples. Samples were collected from 1.5 to 93 meters deep at the site.

3. Bjornstad B.N. 1990. Geohydrology of the 218-W-5 Burial Ground, 200 West Area, Hanford Site. PNL-7336, Pacific Northwest Laboratory, Richland, Washington.

This report summarizes the geologic and hydrologic information available to support performance assessment modeling of the area around the $218-\mathrm{W}-5$ burial ground (W-5). Information in this report includes hydrogeologic data for the saturated and unsaturated zones. Data include particle-size distribution, soil water content, saturated hydraulic conductivity, porosity, storativity, mineralogy, and lithologic profile.

4. Brownell L.E., R.E. Isaacson, J.P. Sloughter, and M.D. Veatch. 1971. Moisture Movement in Soils on the Hanford Reservation. ARH-2068, Atlantic Richfield Hanford Company, Richland, Washington.

This document discusses the potential for deep percolation of soil water and potential transport of radionuclides in Hanford soil. The report examines various soil characteristics to determine if water will percolate through the soil column to the water table. Equations that relate soil water content to matric potential are presented. Theories are tested by examining initial results of a deep well test and related studies to evaluate matric potential in Hanford sediment.

5. Brownell L.E., J.G, Backer, R.E. Isaacson, and D.J. Brown. 1975. Soil Moisture Transport in Arid Site Vadose Zones. ARH-ST-123, Atlantic Richfield Hanford Company, Richland, Washington.

This document discusses the use of two deep (18 meters) lysimeters (1 open, 1 closed bottom) and one uncased well in study of soil moisture transport through Hanford sediment. Data include thermocouple psychrometer and neutron probe measurements. Measurements suggest that the soil moisture profile in relatively constant for long period of time. Consequently, little or no recharge is expected to move below 6 meter depth. 
6. Campbell, M. D., G. W. Gee, M. L. Rockhold, and M. J. Kanyid. 1990. Field Lysimeter Test Facility: Second Year (FY 1989) Test Results. PNL-7209, Pacific Northwest Laboratory, Richland, Washington.

The primary objective of testing protective barriers at the field lysimeter test facility was to measure the water budgets within the various barriers and assess the effectiveness of their designs in limiting water intrusion into the zone beneath each barrier. Four elements of the water budget were measured during the year: precipitation, evaporation, storage, and drainage. A second objective of testing protective barriers at the field lysimeter test facility was to refine procedures and equipment to support data collection for verification of computer models needed for long-term projection of barrier performance. Vegetation cover was also monitored to determine how vegetation affects drainage.

7. Cass A.G., G.S. Campbell, and T.L. Jones. 1981. Hydraulic and Thermal Properties of Soil Samples From the Buried Waster Test Facility. PNL-4015, Pacific Northwest Laboratory, Richland, Washington.

This report discusses the setup of the buried waste test facility. The report includes a discussion of the theory of heat and water flow in soils and relates it to the measured coefficients and properties of the soil from the buried waste test facility. Information in this report includes water retention characteristics, texture, density, and thermal conductivity.

8. Conca J. and T. Montano. 1992. Estimation of Unsaturated Hydraulic Conductivity for Hanford Soils: III. Milestone Report. Unpublished report available from the authors, Richland, Washington.

This report describes results from an investigation into the transport behavior of Hanford Site soil and sediment. Hydraulic conductivities, K, were experimentally determined as a function of volumetric water content, $\theta$, in soil and sediment from three boreholes in the 200 East Area of the Hanford Site to help quantify the release and transport of contaminants to the vadose zone. New unsaturated flow techniques, that have been shown to agree well with traditional methods, were used to directly measure $K(\theta)$ rapidly. The soil tested were 1.8 to 18.3 meters in the Hanford formation. Volumetric water content ranged from $4 \%$ to $34 \%$ with $\mathrm{K}$ values from $6 \times 10^{-9}$ to $4 \times 10^{-3} \mathrm{~cm} / \mathrm{sec}$. The three boreholes, 299-E24-79, 299-E24-92, and 299-E24-95, are relatively closely spaced at about 10 meters. Sediment from borehole 299-W7-99, which was run in the unsaturated flow apparatus during the previous year, was characterized with respect to grain size distribution. Borehole 299-W7-99 sampled the Hanford formation, Paluose soil, Plio-Pleistocene sediment, and Upper Ringold Formation. Data include water content versus hydraulic conductivity, particle-size distribution, and bulk density.

9. Conca J. and T.J. Mockler. 1993. Measurement of Unsaturated Transport Properties in McGee Ranch Soils. Interim Letter Report, Unpublished report available from authors, Richland, Washington.

This report describes measurements of hydraulic properties of McGee Ranch sediment using the unsaturated flow apparatus centrifuge. The hydraulic conductivity, diffusion coefficient, and retardation 
factor for a sediment must be known in order to use existing and developing models of contaminant release to subsurface systems. The unsaturated flow apparatus makes it possible to measure transport parameters in a very short time while replicating the wide range of conditions that exist in the field. This data package includes water content versus hydraulic conductivity and bulk density measurements of 12 sediment samples.

10. Conca J. and T.J. Mockler. 1994. Measurement of Unsaturated Transport Properties in Soils from the ERDF Site. Interim Letter Report, Unpublished report available from authors, Richland, Washington.

Direct measurement of transport parameters on subsurface sediments using the unsaturated flow apparatus method provides detailed unsaturated conductivity relationships for sediment underlying the Environmental Restoration Disposal Facility. Numerical curve fitting routines were then used to estimate matric potential curves from the measured hydraulic conductivity data. Measurements of 12 samples are listed in the data package.

11. Connelly M.P., J.V. Borghese, C.D. Delaney, B.H. Ford, J.W. Lindberg, and S.J. Trent. 1992. Hydrogeologic Model for the 200 East Groundwater Aggregate Area. WHC-SD-EN-TI-019, Westinghouse Hanford Company, Richland, Washington.

The purpose of this document is to provide a comprehensive overview of groundwater flow characteristics in the 200 East Area and identify the extent and nature of groundwater contamination associated with current and historical liquid waste management operations in the 200 East Area. An emphasis has been placed on integrating the available data so that an aggregate area-scale hydrogeologic conceptual model can be constructed. The objectives of this report are: compile and analyze hydrogeological and hydrochemical data collected from within and surrounding the 200 East Area, describe water flow characteristics for both saturated and unsaturated zone, develop a comprehensive hydrogeologic conceptual model for the 200 East groundwater aggregate area, and identify and describe the present nature and extent of groundwater contamination associated with 200 East waste management operations. Moisture retention, saturated hydraulic conductivity, and particle-size distribution data are available for sites at U.S. Ecology, AP1 tank farms, the grout facility, and 200-BP-1.

\section{Connelly M.P., B.H. Ford, and J.V. Borghese. 1992. Hydrogeologic Model of the 200 West Groundwater Aggregate Area. WHC-SD-EN-TI-014, Westinghouse Hanford Company, Richland, Washington.}

The purpose of this document is to provide a comprehensive overview of groundwater flow characteristics in the 200 West Area and identify the extent and nature of groundwater contamination associated with current and historical liquid waste management operations in the 200 West Area. An emphasis has been placed on integrating the available data so that an aggregate area-scale hydrogeologic conceptual model can be constructed. The objectives of this report are: compile and analyze hydrogeological and hydrochemical data collected from within and surrounding the 200 West Area, describe water flow characteristics for both saturated and unsaturated zone, develop a comprehensive hydrogeologic conceptual model for the 200 West groundwater aggregate area, and identify and describe the present 
nature and extent of groundwater contamination associated with 200 West waste management operations. There are 55 unsaturated samples from 200 West boreholes listed in this report. Data includes water retention, saturated hydraulic conductivity, particle-size distribution, and calculated van Genuchten parameters.

\section{Delaney C. 1992. W-049H Borehole Summary Report. WHC-SD-EN-DP-065, Westinghouse Hanford Company, Richland, Washington.}

This report summarizes the data collected from wells drilled for the purpose of characterization of the W-049H facility east of the 200 East Area. This report includes laboratory data for soil water retention, sieve analysis, bulk density, and saturated hydraulic conductivity for discrete samples collected at the boreholes.

14. DynCorp. 2000. Hanford Solid Waste Landfill Closure Plan. HNF-7173, Rev. 0, DynCorp TriCities Services, Inc., Richland, Washington.

15. Enfield J., J.C. Hsieh, and A.W. Warrick. 1973. "Evaluation of Water Flux Above a Deep Water Table Using Thermocouple Psychrometers.”Soil Sci. Soc. Am. Proc., 37:968-970.

16. Engelman R.E., R.E. Lewis, D.C. Stromswold, and J.R. Hearst. 1995. Calibration Models for Measuring Moisture in Unsaturated Formations by Neutron Probe. PNL-10801, Pacific Northwest Laboratory, Richland, Washington.

This document reports on the calibration process for neutron probe instrumentation used at Hanford. The document bases the moisture content range and bulk density for test samples on sediment data collected at Hanford. Based on the Hanford data, expected neutron counts for variable moisture contents and bulk densities are derived. The data sources used to arrive at representative Hanford properties are listed including 3,600 analyses from the Hanford formation located on the HEIS database.

17. Fayer M.J., M.L. Rockhold, and M.D. Campbell. 1992. "Hydrologic modeling of protective barriers: Comparison of field data and simulation results." Soil Sci. Soc. of Am. J. 56:690-700.

18. Fayer M.J. and C.S. Simmons. 1995. "Modified soil water retention functions for all suctions heads." Water Resour. Res. 31:1233-1238.

19. Fayer M.J., R.E. Lewis, R.E. Engelman, A.L. Pearson, C.J. Murray, J.L. Smoot, R.R. Randall, W.H. Wegener, and A.H. Lu. 1995. Re-Evaluation of a Subsurface Injection Experiment for Testing Flow and Transport Models. PNL-10860, Pacific Northwest Laboratory, Richland, Washington.

This document is intended to perform and analyze field experiments to demonstrate the appropriateness of conceptual models for performance assessment. The most convincing way to demonstrate appropriateness is to show that the model can reproduce the movement of water and contaminants in the field. The objective of this report was to log the injection site with the latest geophysical tools to provide a better estimate of water contents, refine the stratigraphic conceptual model, and ultimately provide a data set 
sufficiently complete, detailed and accurate to enable effective testing of models. All wells at the injection site were logged for water content, density, and gamma emissions.

20. Fayer M.J. and T.B. Walters. 1995. Estimated Recharge Rates at the Hanford Site. PNL-10285, Pacific Northwest Laboratory, Richland, Washington.

The Ground-Water Surveillance Project monitors the distribution of contaminants in groundwater at the Hanford Site for the U.S. Department of Energy. A subtask called "Water Budget" was initiated in FY94. The objective of this subtask was to produce a defensible map of estimated recharge across the Hanford Site. Recharge rates are a function of the topography, climate, soil type, and vegetation. This document includes maps of recharge and vegetation coverage for the Hanford Site. Information in this report includes soil water storage and soil moisture profiles from field experimental sites, as well as climate data. Soil hydraulic properties were also derived for a typical range of surface soil found at Hanford.

21. Fayer M.J., G.W. Gee, M.L. Rockhold, M.D. Freshley, and T.B. Walters. 1996. "Estimating Recharge Rates for a Ground-Water Model Using a GIS.” J. Environ. Qual. 25:510-518.

22. Fayer M.J., E.M. Murphy, J.L. Downs, F.O. Khan, C.W. Lindenmeier, and B.N. Bjornstad. 1999. Recharge Data Package for the Immobilized Low-Activity Waste 2001 Performance Assessment. PNNL-13033, Pacific Northwest National Laboratory, Richland, Washington.

Recharge rates are the primary mechanism for transporting contaminants to the groundwater. The elements of this report compose the recharge data package, which provides estimates of recharge rates for the scenarios being considered in the 2001 performance assessment. Surface features evaluated for recharge include the modified RCRA subtitle $\mathrm{C}$ cover, cover sideslopes, Rupert sand, Burbank loamy sand, and Hanford formation sediment. Recharge was derived from field observations at lysimeter sites, by measurement of a natural tracer in a soil column, and through modeling analyses.

\section{Fayer M.J. 2000. UNSAT-H version 3.0: Unsaturated Soil Water and Heat Flow Model, Theory, Users Manual, and Examples. PNNL-13249, Pacific Northwest National Laboratory, Richland, Washington.}

UNSAT-H is a FORTRAN computer code used to simulate the one-dimensional flow of water, vapor, and heat in soil. The code addresses the processes of precipitation, evaporation, plant transpiration, storage, and deep drainage. Further information about UNSAT-H is available at http://hydrology.pnl.gov/resources.asp.

24. Fecht, K.R, B.N. Bjornstad, D.G. Horton, G.V Last, S.P. Reidel, and K.A. Lindsey. 1999. Clastic Injection Dikes of the Pasco Basin and Vicinity. BHI-01103, Bechtel Hanford Company, Richland, Washington.

The atlas provides a summary of the current understanding of the clastic injection dikes of the Pasco Basin and vicinity. The atlas is a compilation of maps, photographs, tables and text that provides a summary of the physical description, emplacement history and mechanisms, and hydraulic characteristics 
of clastic injection dikes. The information that is assembled is based on geologic, geophysical, and geohydrologic investigations conducted at the Pasco Basin and vicinity. Of particular interest for this document is Chapter 9, "Hydraulic Testing." Information includes field infiltration tests, laboratory measurement of the hydraulic conductivity, as a function of the moisture content using the unsaturated flow apparatus method, gas conductivity using the unsaturated flow apparatus method, and sieve analysis.

25. Finlayson B.A., R.W. Nelson, and R.G. Baca. 1978. A Preliminary Investigation into the Theory and Techniques of Modeling Natural Moisture Movement in Unsaturated Sediments. RHO-LD-47, Rockwell Hanford Operations, Richland, Washington.

This report discusses the problems in developing a computer model of fluid flow processes in arid soil systems. A detailed discussion includes model assumptions and numerical techniques required to solve a highly complex, non-linear flow problem. The developed code was then used to compare model results to field results of soil moisture profile at a lysimeters site. The comparison showed that the results showed qualitative agreement, however, the overall fit of the data was deemed poor.

26. Freeman E.J. 1995. Fractal Geometries Applied to Particle Size Distribution and Related Moisture Retention Measurements at Hanford, Washington. Masters Thesis, University of Idaho, Moscow, Idaho.

Use of indirect methods to derive water retention properties include the use of particle-size distribution data to arrive at a scaling coefficient which is then used to calculate a corresponding water retention function for the soil (pedotransfer function). Two fractal methods were used to derive scaling coefficients for Hanford soil. Particle size distribution and water retention data for a texturally diverse sample population were derived from 48 Hanford samples and 7 samples reported in published literature to test the fractal scheme.

27. Gee G.W. and C.S. Simmons. 1979. Characterization of the Hanford 300 Area Burial Grounds: Task III - Fluid Transport and Modeling. PNL-2921, Pacific Northwest Laboratory, Richland, Washington.

This report describes a model, developed and applied to the 300 Area burial grounds to analyze the influence of potential evaporation and rainfall patterns on drainage. The model describes onedimensional unsaturated flow. The methodology used includes measurement and modeling techniques that can be applied to other burial sites to characterize water migration and hence be used as a framework which radionuclide migration can be predicted. Data collected during this work include water retention, hydraulic conductivity due to a thermal gradient, water content profiles, soil-water storage, seepage, and evapotranspiration, unsaturated hydraulic conductivity derived from the water retention curve. 
28. Gee G.W. and A.C. Campbell. 1980. Monitoring and Physical Characterization of Unsaturated Zone Transport, Laboratory Analysis. PNL-3304, Pacific Northwest Laboratory, Richland, Washington.

This report discusses sorption of radionuclides by a sandy soil, typical of Hanford sediment. Measured unsaturated hydraulic conductivities for the sediments ranged from 2.2 to $49 \mathrm{~cm} /$ day as volumetric water contents varied from $31 \%$ to $56 \%$ (saturation).

29. Gee G.W., A.C. Campbell, P.J. Wierenga, and T.L. Jones. 1981. Unsaturated Moisture and Radionuclide Transport. PNL-3616, Pacific Northwest Laboratory, Richland, Washington.

This report describes several laboratory procedures and computer model simulations used to evaluate the transport of water and radionuclides through unsaturated Hanford soil. Unsaturated hydraulic conductivity was measured by the stead-state head control method and the transient state method. The conductivity data was then compared to standard conductivity models. Results for hydraulic conductivity at the wet range showed good agreement, however, those measurements in the dry range under-predicted the conductivity. None of the models addressed vapor flow, which may account for the poor performance of in the dry range. Radionuclide transport was investigated by using the two-parameters convectivedispersive model and the four-parameter mobile-immobile water model for the radionuclides strontium-85 and tritium. Both models showed good agreement.

30. Gee G.W. and R.R. Kirkham. 1984. Arid Site Water Balance: Evapotranspiration Modeling and Measurement. PNL-5177, Pacific Northwest Laboratory, Richland, Washington.

Transport of contaminant materials through the unsaturated sediment is expected to be the dominant pathway for contaminant migration at most shallow land burial sites. To evaluate the magnitude of transport at an arid site, Pacific Northwest Laboratory conducted a field and modeling study to measure and predict water movement under vegetated and bare soil conditions. Drainage measurements during 1983 and 1984 suggest that water infiltrated beyond the shallow roots of the grasses of the Hanford Grass Site. Moisture was able to move beneath the roots because precipitation during observation was wetter than normal $(28 \mathrm{~cm} / \mathrm{yr}$ versus the normal $16 \mathrm{~cm} / \mathrm{yr}$ ) and infiltration occurred when evapotranspiration was low. In addition to measurement of water content, precipitation, water storage, drainage, and the water content profile, a one-dimensional model was used to match model results to measured data.

31. Gee G.W. and T.L. Jones. 1985. Lysimeters at the Hanford Site: Present Use and Future Needs. PNL-5578, Pacific Northwest Laboratory, Richland, Washington.

The report describes the design features of six major lysimeter facilities at Hanford and the types of data available from them. The six lysimeter sites include the 200 East deep lysimeters, biointrusion lysimeter, buried waste test facility lysimeters, special waste test facility lysimeters, grout waste test facility lysimeters, and the Arid Lands Ecology reserve lysimeters. 
32. Gee G.W. and P.R. Heller. 1985. Unsaturated Water Flow at the Hanford Site: Review of Literature and Annotated Bibliography. PNL-5428, Pacific Northwest Laboratory, Richland, Washington.

This work will be helpful in assessing the probability that water infiltrating the ground surface may eventually contribute to ground-water recharge at the Hanford Site. Reports are reviewed for their pertinence to unsaturated water flow and specifically for information that could help resolve the question of whether recharge of the unconfined aquifer by natural precipitation is occurring on the Hanford Site, and if so, what are the expected ranges of recharge. General conclusions of the report include water content at depth is about $2 \%$ to $7 \%$ in coarse to medium sand and $7 \%$ to $15 \%$ silt, water is draining toward the water table. Plants contribute to whether there is drainage or not. Data in the report include lysimeter data and abstracts from relevant reports published prior to 1985.

33. Gee G.W., M.L. Rockhold, and J.L. Downs. 1989. Status of FY 1988 Soil-Water Balance Studies at the Hanford Site. PNL-6750, Pacific Northwest Laboratory, Richland, Washington.

The purpose of this study is to quantify the Hanford Site's natural recharge by detailed study of water balance parameters (i.e., precipitation, change in soil water storage, evapotranspiration, and drainage). Two field experiments to measure hydraulic properties at the Grass Site were conducted using the unsteady drainage-flux method. In addition to the Grass Site, McGee Ranch site was also evaluated. Data from particle-size analysis was used to calculate water content and hydraulic conductivity. Fractal mathematics were used to estimate parameters needed to predict water release (drainage) characteristics. Data collected for these sites include precipitation records, water storage data, drainage measurements, and hydraulic properties. Laboratory measured water content and particle-size distribution was also collected.

34. Gee G.W., R.R. Kirkham, J.L. Downs, and M.D. Campbell. 1989. The Field Lysimeter Test Facility (FLTF) at the Hanford Site: Installation and Initial Tests. PNL-6810, Pacific Northwest Laboratory, Richland, Washington.

The objective of this project is to test barrier design concept and to demonstrate a barrier design that meets established performance criteria for use in isolating waste disposed of near-surface at the Hanford Site. Also, to assess barrier performance and design with respect to infiltration control, field lysimeters and small- and large-scale field plots under actual and modified climatic conditions. The facility consists of 14 drainage lysimeters ( 2 meters X 3 meters deep) and 4 weighing lysimeters ( 1.5 meters X 1.5 meters X 1.7 meters deep). In November 1987, tests were begun to measure water infiltration, evapotranspiration, redistribution within the soil profile, and drainage. Laboratory data on the hydraulic properties of the materials used include saturated hydraulic conductivity, water retention, soil bulk density, and particle-size distribution (16 samples). Field data are obtained to evaluate moisture storage profiles and saturated hydraulic conductivity.

35. Gee G.W., M.J. Fayer, M.L. Rockhold, and M.D. Campbell. 1992. "Variation in Recharge at the Hanford Site." Northwest Sci. 66:237-250. 
36. Gee G.W., H.D. Freeman, W.H. Walters, Jr., M.W. Ligotke, M.D. Campbell, A.L. Ward, S.O. Link, S.K. Smith, B.G. Gilmore, and R.A. Romine. 1994. Hanford Prototype Surface Barrier Status Report: FY 1994. PNL 10275, Pacific Northwest Laboratory, Richland, Washington.

The objective of the current barrier design is to use natural materials to develop a protective barrier system that isolates wastes for at least 1,000 years by limiting water, plant, animal, human intrusion, and minimizing erosion. This document describes the design and initial performance of barrier materials. Hydraulic conductivity of the asphalt was performed with a falling-head permeameter. Wind erosion potential was also measured for the barrier surface material. During an irrigation campaign, water distribution and water storage in the soil profile was monitored.

37. Gee G.W., P.J. Wierenga, B.J. Andraski, M.H. Young, M.J. Fayer, and M.L. Rockhold. 1994. "Variations in Water Balance and Recharge Potential at Three Western Desert Sites." Soil Sci. Soc. Am. J. 58:63-72.

38. Gee G.W., A.L. Ward, and M.J. Fayer. 1997. "Surface Barrier Research at the Hanford Site." Land Contam. Reclam. 5(3):233-238.

39. Heller P.R., G.W. Gee, and D.A. Myers. 1985. Moisture and Textural Variations in Unsaturated Soils/Sediments Near the Hanford Wye Barricade. PNL-5377, Pacific Northwest Laboratory, Richland, Washington.

This report documents an effort to hydrologically characterize vadose zone sediment at Hanford. The report details measurements of field water contents for samples collected from five boreholes drilled a few kilometers west of the Wye barricade, about 15 kilometers northwest of Richland, Washington. Laboratory analyses were performed on samples for all holes to determine particle-size, water retention characteristics, hydraulic conductivity, calcium carbonate content, $\mathrm{pH}$, and electrical conductivity. Thermocouple psychrometer data were used to index the matric water potential of field samples from three of the five holes. Results are tabulated by hole and depth and a general discussion regarding the use of this information for hydrologic modeling is provided.

40. Heller P.R. 1989. "Physical Analysis for Grout Study." In Smoot J.L., J.L. Szecsody, B. Sagar, G.W. Gee, and C.T. Kincaid, Simulation of Infiltration of Meteoric Water and Contaminant Plume Movement in the Vadose Zone at the Single-Shell Tank 241-T-106 at the Hanford Site. WHC-EP-0332, Westinghouse Hanford Company, Richland, Washington.

The appendix by P. R. Heller is the results section of laboratory analysis of six samples from the AP tank farm in the 200 East Area. Data in the report include water content versus pressure head, sieve analysis, and bulk density measurements. 
41. Hoffman K.M. 1992. 200-BP-1 Borehole Summary Report for Tasks 2, 4, and 6. WHC-SD-ENTI-054, Westinghouse Hanford Company, Richland, Washington.

This report lists the physical and hydraulic properties for borehole samples from the 200-BP-1 site, including particle-size distribution, water retention data, and bulk density.

\section{Hsieh J.J.C., A.E. Reisenauer, and L.E. Brownell. 1973. A Study of Soil Matric Potential and Temperature in Hanford Soils. BNWL-1712, Battelle, Pacific Northwest Laboratory, Richland, Washington.}

This document describes the construction and installation of a string of thermocouple psychrometers and diode temperature transducers in the soil between the soil surface and the water table. The results of 15 months of data gathering from these instruments indicated that moisture movement in the soil profile is very small. Information in this report includes sieve analyses, and water retention and temperature at discrete depth intervals $(1970$ - 1972). The experimental site was an uncased well 5 kilometers south of the 200 East Area.

43. Hsieh J.J.C., L.E. Brownell, and A.E. Reisenauer. 1973. Lysimeter Experiment Description and Progress Report on Neutron Measurements. BNWL-1711, Battelle Northwest Laboratories, Richland, Washington.

This report describes the installation and operation of the deep lysimeters test site for an interval of 3 years. The deep lysimeters are located 4.8 kilometers southeast of the 300 Area. The lysimeters are 3 meters in diameter and 18 meters deep. The purpose of the lysimeters was to determine whether meteoric water percolates down to the water table at the 200 Area plateau. Instrumentation of the lysimeters consisted of thermocouple psychrometers, neutron probe, and pressure sensors, which were monitored from a central instrumentation room. Data include time and depth measurements of water content and near surface, diurnal temperature measurements.

44. Isaacson R.E., L.E. Brownell, and J.C. Hanson. 1974. Soil Moisture Transport in Arid Vadose Zone. ARH-2983, Atlantic Richfield Hanford Company, Richland, Washington.

This report describes soil moisture transport processes in the arid soil of the Hanford Site. The depth of penetration of meteoric precipitation has been determined by profiling fall-out tritium. In-situ temperature transducers and thermocouple psychrometer measurements were used to measure temperature and water potential. Neutron probe data were used to measure moisture profile in the two lysimeters of the 200 East Area deep lysimeters.

45. Isaacson R.E. 1982. Supporting Information for the Scientific Basis for Establishing Dry Well Monitoring Frequencies. RHO-RE-EV-4-P, Rockwell Hanford Operations, Richland, Washington.

This document discusses the scientific basis for establishing the frequency of monitoring dry wells. Information contained in this report includes detailed graphs, tables, pictures, and locations of waste tanks in the 200 Areas. Neutron probe determined moisture contents for soil in the tank farms are listed. 
46. Jones T.L. 1978. Sediment Moisture Relationships: Lysimeters Project 1967-1977 Water Year. RHO-ST-15, Rockwell Hanford Operations, Richland, Washington.

This report discusses the two lysimeters of the 200 East Area deep lysimeter site for the water years 1967 through 1977. Some of the limitations of using neutron probes in resolving moisture content differences and the importance of knowing soil hydraulic conductivity are also reviewed.

47. Jones T.L., G.S. Campbell, and G.W. Gee. 1984. Water Balance at an Arid Site: Model Validation Study of Bare Soil Evaporation. PNL-4896, Pacific Northwest Laboratory, Richland, Washington.

This report contains results of model validation studies. The model validation tests consist of using unsaturated water flow models to simulate water balance experiments conducted at the buried waste test facility. The facility is a lysimeter facility designed to collect field data on long-term water balance and radionuclide tracer movement. The major focus of the validation study was to evaluate how the use of different evaporation models affect the accuracy of predictions of evaporation, storage, and drainage made by the whole model.

48. Jones T.L. and G.W. Gee. 1984. Assessment of Unsaturated Zone Transport for Shallow Land Burial of Radioactive Waste: Summary Report of Technology Needs, Model Verification, and Measurement Efforts (FY78-FY83). PNL-4747, Pacific Northwest Laboratory, Richland, Washington.

Two main topics are addressed in this report. The first topic relates to the assessment process for shallow land burial site design. This overview includes basic descriptions of water balance, transport processes, and technology needs for waste management at and arid (dry) site. The second topic deals with specific results of research activities at Pacific Northwest Laboratory related to water and radionuclide transport under arid shallow land burial. Water balance data, collected since FY 1978 at the buried waste test facility at Hanford, are used to illustrate the influence of climate variables on soil water storage and drainage at an arid site.

49. Jones T.L., R.J. Serne, and A.P. Toste. 1988. Special Waste-Form Lysimeters-Arid: Three-Year Monitoring Report. PNL-6400, Pacific Northwest Laboratory, Richland, Washington.

The primary method used by this program is to bury sample waste forms in field lysimeters and monitor leachate composition from the release and transport of solutions. The lysimeter facility consists of 10 lysimeters, each containing one sample of solidified waste. The hydrologic environment of the lysimeters shows rather large seasonal variations. The volumetric water content at the depth of the waste samples ranges from approximately $11 \%$ in the late winter to a low of about $7 \%$ in the late summer. Drainage rates also vary from winter to summer. Volumetric water content was monitored at the site using neutron probe. Lysimeters were instrumented with thermocouples to measure the vertical soil temperature profile, fiberglass resistance blocks to monitor soil water potential, and suction candles to allow extraction of soil solution. 
50. Jones, T.L. and R.J. Serne. 1994. Special Waste-Form Lysimeter-Arid 1984-1992 Data Summary and Preliminary Interpretation. PNL-8955, Pacific Northwest Laboratory, Richland, Washington.

A lysimeter facility constructed at the Hanford Site in south-central Washington state has been used since 1984 to monitor the leaching of buried waste forms under natural conditions. The facility is generating data that are useful in evaluating source-term models used in radioactive transport analyses. The facility includes 10 bare-soil lysimeters containing buried waste forms generated at nuclear reactors in the United States and solidified with Portland III cement, masonry cement, bitumen, and vinyl-ester styrene. The waste forms contained in the lysimeters have been leached under natural, semiarid conditions. In spite of the semiarid conditions, 1984 through 1992, an average of 45 centimeters of water leached through the lysimeters, representing $27 \%$ of area precipitation. Appendices in this report include precipitation data, water storage and water content, drainage data, release data, and leachate chemistry data.

\section{Khaleel R. and E.J. Freeman. 1995. Variability and Scaling of Hydraulic Properties for 200 Area Soils, Hanford Site. WHC-EP-0883, Westinghouse Hanford Company, Richland, Washington.}

Information on particle size distribution, hydraulic properties derived from water content versus pressure head, and saturated hydraulic conductivity was collected for 183 samples at 12 sites in the 200 Area plateau. These data were derived from laboratory measurements. Measurements were corrected for additional gravel content and the primary drying curve was adjusted, as necessary, to generate a set of corrected hydraulic properties that represent the depositional environment. Once the corrected parameters were derived, the sediments were separated into six textural classes and a scaling function was used to calculate a texture-based type curve for each of the textural classes. The final step was to fit a Kolmogorov-Smirnov (K-S) goodness-of-fit cumulative distribution curve to the scaled and unscaled data. Since a normal distribution may not always represent natural material properties, a transform function was applied that would potentially improve the data fit to the K-S curve.

52. Khaleel R., J.F. Relyea, and J.L. Conca. 1995. "Evaluation of van Genuchten-Mualem Relationships to Estimate Unsaturated Hydraulic Conductivity at Lower Water Content." Water Resour. Res., vol. 31, no. 11, pp. 2659-2668.

53. Khaleel $R$ and J.F. Relyea. 1997. "Correcting Laboratory-Measured Moisture Retention Data for Gravel.” Water Resour. Res., vol. 33, no. 8, pp. 1875-1878.

\section{Khaleel R. 1999. Far-Field Hydrology Data Package for Immobilized Low-Activity Tank Waste Performance Assessment. HNF-4769 Rev. 1, Fluor Federal Services, Richland, Washington.}

This report presents the laboratory measurements on physical and hydraulic properties for soil samples at the immobilized low-activity waste disposal site, and results of application of stochastic theory to smallscale measurements. The effective (upscaled) parameter estimates are derived for saturated hydraulic conductivity, soil water content, and unsaturated hydraulic conductivity, bulk density, unretarded macrodispersivity, and sorption enhanced macrodispersivity. The stratigraphy at the disposal site is dominantly 
of two types. The upper vadose zone is characterized as a sandy sequence, whereas the lower vadose zone is characterized primarily by a gravel-dominated sequence. A methodology is presented to estimate uncertainties in model predictions.

55. Khaleel R. 2000. Model Data Package for S-SX Field Investigation Report (FIR). RPP-6296 REV. 0, Fluor Federal Services, Richland, Washington.

This report documents the data that will be used as input to perform flow and transport modeling through the vadose zone and unconfined aquifer. Included are the results of analysis of laboratory measurements for physical and hydraulic properties for soil samples in the vicinity of S-SX tank farms, and results on application of stochastic theory to small-scale measurements. Effective (upscaled) parameter estimates are derived from saturated hydraulic conductivity, soil moisture retention, unsaturated hydraulic conductivity, bulk density, unretarded macrodispersivity, and sorption enhanced macrodisperivity.

56. Khaleel, R. and J.F. Relyea. 2001. "Variability for Gardner's $\alpha$ for Coarse-Textured Sediments." Water Resour. Res., vol. 37, no. 6, pp. 1567-1575.

57. Kirkham R.R. and G.W. Gee. 1984. Measurement of Unsaturated Flow Below the Root Zone at an Arid Site. PNL-SA-116229, Pacific Northwest Laboratory, Richland, Washington.

This report documents moisture content change below the root zone of a grass covers site. Moisture content profiles were measured at depth, with a down-well neutron probe. These data were then used to estimate drainage below the root zone. Results confirm that drainage in the coarse sand does occur beneath the root zone. Unsaturated flow model simulations predicted about 5 centimeters drainage from the Grass Site using daily climatic data, estimated soil hydraulic properties, and estimated transpiration properties for cheatgrass at the Hanford Site.

58. Kirkham R.R., G.W. Gee, and T.L. Jones. 1984. "Weighing Lysimeters for Long-Term Water Balance Investigations at Remote Sites.” Soil Sci. Soc. Am. J. 48:1203-1205.

59. Kirkham R.R., G.W. Gee, and J.L. Downs. 1987. Field Lysimeter Test Facility for Protective Barriers: Experimental Plan. PNL-6351, Pacific Northwest Laboratory, Richland, Washington.

The field lysimeter test facility was built to test selected protective barrier designs. The facility consists of 18 lysimeters (14 drainage and 4 weighing lysimeters). Instrumentation for these lysimeters includes neutron probe access tubes, tensiometers, and thermocouples.

60. Kirkham R.R., M.L. Rockhold, G.W. Gee, M.J. Fayer, M.D. Campbell, and L.J. Fritschen. 1991. "Lysimeters: Data acquisition and analysis." In Proceedings of the International Symposium on Lysimetry, ed. R.G. Allen, pp. 362-370, American Society of Civil Engineers, New York. 
61. Last G.V., P.G. Easley, and D.J. Brown. 1976. Soil Moisture Transport During the 1974-1975 and 1975-1976 Water Years. ARH-ST-146, Atlantic Richfield Hanford, Richland, Washington.

The rate and direction of soil moisture movement in Hanford sediment was determined for the 1974-1975 and 1975-1976 water years. The data for these determination were obtained from two large lysimeters located in the 200 Area Plateau near the center of the Hanford Reservation. During the 1974-1975 water year, meteoric moisture percolated to a depth of 2.5 meters with a peak moisture content of $10.5 \% \mathrm{vol}$. This percolation envelop was eliminated by evaporation during the hot summer of 1975. Moisture content of sediment in the 4 to 18 meter depth range showed no relative change throughout the 2 years and no moisture accumulation at the bottom of the lysimeter, which indicates there is no percolation of meteoric moisture at this site, and no recharge to the groundwater.

62. Last G.V., M.A. Glennon, M.A. Young, and G.W. Gee. 1987. Protective Barrier Materials Analysis: Fine Soil Site Characterization. PNL-6314, Pacific Northwest Laboratory, Richland, Washington.

Soil samples were collected for the physical characterization of a potential fine-soil quarry site at McGee Ranch during May and June 1986. The ranch is located approximately 1 kilometer northwest of the Hanford Site Yakima Barricade. Forty test boreholes were made using a hollow-stem auger. The physical characterization of the fine soil sampled near McGee Ranch indicates that $3.4 \mathrm{Mm}^{3}$ of soil met or exceeded the minimum grain-size requirement needed for the protective barrier program. Measurements through the profile include soil moisture distribution and particle-size distribution.

63. Last G.V., R.J. Serne, and V.L. LeGore. 1995. Field Lysimeter Studies for Performance Evaluation of Grouted Hanford Defense Wastes. PNL-10166, Pacific Northwest Laboratory, Richland, Washington.

This report discusses the design of the grout waste test facility, presents the routine data collected from this facility between 1985 and January 1989 and subsequent data collected sporadically between 1989 and 1993, and provides a brief discussion concerning preliminary interpretation of the results. The facility consists of four, 8 meters deep by 2 meters diameter close-bottom caisson lysimeters. A grout waste package was placed in each lysimeter and leachate drainage was monitored. Information in this report includes soil temperature, moisture block resistance, soil water content, water balance, neutron probe and gross gamma logs.

64. Last G.V. and D.G. Horton. 2000. Review of Geophysical Characterization Methods Used at the Hanford Site. PNNL-13149, Pacific Northwest National Laboratory, Richland, Washington.

This paper presents a review of geophysical methods used at Hanford in two parts: 1) shallow surfacebased geophysical methods and 2) borehole geophysical methods. This review is not intended to be "all encompassing" but should represent the vast majority ( $>90 \%)$ of the geophysical work conducted onsite and aimed at hazardous waste investigations in the vadose zone and/or upper most groundwater aquifers. 
65. Liikala T.L., R.L. Aaberg, N.J. Aimo, D.J. Bates, T.J. Gilmore, E.J. Jensen, G.V. Last, P.L. Oberlander, K.B. Olsen, K.R. Oster, L.R. Roome, J.C. Simpson, S.S. Teel, and E.J. Westergard. 1988. Geohydrologic Characterization of the Area Surrounding the 183-H Solar Evaporation Basins. PNL-6728, Pacific Northwest Laboratory, Richland, Washington.

This report describes groundwater characterization and monitoring activities at the 183-H solar evaporation basins from 1985 through 1988. Data included in the report are water content profiles and water retention data for 19 wells and natural-gamma, neutron, and density logs.

66. Link S.O., R.N. Kickert, M.J. Fayer, and G.W. Gee. 1993. A Comparison of Simulation Models for Predicting Soil Water Dynamics in Bare and Vegetated Lysimeters. PNL-8675, Pacific Northwest Laboratory, Richland, Washington.

This report describes the results of simulation models used to predict soil water storage dynamics at the field lysimeter test facility weighing lysimeters. The objective of this research is to develop the capability to predict soil water storage dynamics with plants in support of water infiltration control studies for the Hanford Permanent Isolation Barrier Development Program.

67. McDonald J., V. Chipman, N. Mason, and W. Lowry. 2001. In-Situ Air Permeability at the Hanford 200 East Area. SEASF-FR-01-261 REV 1, Science and Engineering Associates, Santa Fe, New Mexico.

In situ air permeability measurements of the soil at the Hanford 200 East Area were performed for borehole $\mathrm{C} 3177$. The purpose of the measurements was to characterize the in situ air permeability of the soil at specific depths from within the advancing borehole. This report documents the methods, field activities, and results of the air permeability measurements. A total of eight measurements were taken at select locations during drilling. Three of these measurements were taken in Hanford sands and the other five were taken in the lower Hanford gravel.

68. McHenry J.R. 1957. Properties of Soils of the Hanford Project. HW-53218, Hanford Atomic Products Operations, General Electric Company, Richland, Washington.

This report presents compilation of the complete results obtained from a number of laboratory test performed on soil samples selected as representative of various Hanford project well locations. Characteristics measured include sieve analyses, $\mathrm{pH}, 15$ bar water contents and cation exchange capacity.

69. Meyer P.D. and R.J. Serne. 1999. Near Field Hydrology Data Package for the Immobilized LowActivity Waste 2001 Performance Assessment. PNNL-13035, Pacific Northwest National Laboratory, Richland Washington.

This report provides an estimate of the physical, hydraulic and transport properties of the materials comprising the disposal facilities and the disturbed region around the proposed immobilized low-activity waste site. Properties are expressed as parameters of constitutive models used in simulations of 
subsurface flow and transport. In addition to the best-estimate parameter values, information on uncertainty in the parameter values and estimates of the changes in parameter values over time are required.

70. Meyer P.D. and G.W. Gee. 1999. “Flux-Based Estimation of Field Capacity.” J. Geotech. and Geoenviron. Engr. 125(7):595-599.

71. Narbutovskih S.M., D.F. Iwatate, M.D. Sweeney, A.L. Ramirez, W. Daily, R.M. Morey, and L. Christensen. 1996. Feasibility of CPT-Deployed Vertical Electrode Array in Single Shell Tank Farms. WHC-SD-EN-TA-004, Westinghouse Hanford Company, Richland, Washington.

This report documents the design and construction of the mock tank site, as well as the simulated injection event and results of monitoring the resultant plume with the ERT device.

72. Nelson R.W. and A.E. Reisenauer. 1961. Analysis of 100-N Disposal Crib Influence on the Sanitary Tile Field. HW-70058, Hanford Laboratories Operations, Richland, Washington.

This document describes the possibility of flooding at the sanitary tile field next to crib operations at 100-N Area. An analytical approach was used that calculated fluid flow based on outflow from the crib using the method of flow lines. This is one of the first published papers regarding unsaturated flow at the Hanford Site.

73. Pacific Northwest Laboratory. 1992. Procedures for Ground-Water Investigations. PNL-6894 Rev. 1, Pacific Northwest Laboratory, Richland, Washington.

This document replaced PNL-MA-567. This manual was developed by the Pacific Northwest Laboratory to document the procedures used to carry out and control the technical aspects of ground-water investigations at the Pacific Northwest Laboratory. National Standards including the American Society of Testing and Materials and U.S. Geological Survey were utilized in developing the procedures.

74. Ramirez A., W. Daily, A. Binley, D. LaBrecque, and D. Roelant. 1996. "Detection of Leaks in Underground Storage Tanks Using Electrical Resistance Methods.” J. of Environ. And Eng.

Geoph., vol. 1, no. 3, pp. 189-203.

This document provides a summary of field experiment results performed under a 15 -meter diameter steel tank at Hanford, Washington. Field results are used to extrapolate how this technique could be used to detect and locate leaks and to delineate any resulting plumes from underground storage tanks.

75. Reisenauer A.E. and R.W. Nelson. 1963. "Some Influences of Soils and Water Table Depths on Seepage from Unlined Canals." In Seepage Symposium Proceedings, Phoenix, Arizona, ARS 41-90, U.S. Department of Agriculture, Washington, D.C., pp. 68 - 75. 
76. Reisenauer A.E. 1973. Calculation of Soil Hydraulic Conductivity from Soil-Water Retention Relationships. BNWL-1710, Battelle Pacific Northwest Laboratory, Richland, Washington.

This document describes the mathematical equation for calculating the hydraulic conductivity-suction relationship from moisture content versus suction measurements and the computer code written to solve the equation. The calculation was performed for six texturally different Hanford soil for which unsaturated hydraulic conductivity was known. Results show that the calculated data fits the measured data reasonably well.

77. Reisenauer A.E. and R.J. Serne. 1974. Water Flux in the Vadose Zone Beneath the 200 Area Plateau. Personal communication, available from the authors.

This communication discusses the effects of hydraulic gradient and thermal gradients on water flow in the unsaturated Hanford sediment. Measurements were taken at a lysimeter and instrumented well. The equations developed here are intended to incorporate all factors necessary to define total water flux in the vadose zone. Information included the unsaturated hydraulic conductivity and sieve analyses data.

78. Reisenauer A.E., D.B. Cearlock, and C.A. Bryan. 1975. Partially Saturated Transient Groundwater Flow Model Theory and Numerical Implementation. BNWL-1713, Battelle Pacific Northwest Laboratory, Richland, Washington.

This report describes the mathematical development of the partially-saturated transient flow computer model used to test the formulation for simulated isothermal, unsaturated, liquid flow in heterogeneous porous media. The complexity associated with a sharp wetting front in the calculation is also noted. Data included in this report include moisture retention and unsaturated hydraulic conductivity for four Hanford sediment.

\section{Rockhold M.L., M.J. Fayer, and G.W. Gee. 1988. Characterization of Unsaturated Hydraulic} Conductivity at the Hanford Site. PNL-6488, Pacific Northwest Laboratory, Richland, Washington.

This document describes a study to evaluate methods for measuring and predicting unsaturated hydraulic conductivities. This report details some recent field measurements and compares predicted and measured values of hydraulic conductivities for three locations at the Hanford Site. Measurements from small "point" and large "plot" areas utilized infiltration and drainage techniques to obtain in situ data for fieldsaturated and unsaturated hydraulic conductivities. Steady-state techniques were used to measure unsaturated hydraulic conductivities in small columns in the laboratory for one of the three soils tested to provide a comparison with data obtained from the field. The three sites where measurements were taken include the buried waste test facility, the Grass Site, and McGee Ranch. Investigators used a particle-size distribution to estimate water retention characteristics and, subsequently, to predict unsaturated hydraulic conductivities. Measurements of water retention characteristics are necessary to determine parameter value used in one of the models. 
80. Rockhold M.L., M.J. Fayer, G.W. Gee, and M.J. Kanyid. 1990. Natural Groundwater Recharge and Water Balance at the Hanford Site. PNL-7215, Pacific Northwest Laboratory, Richland, Washington.

The purpose of this report is to present water-balance data collected in 1988 and 1989 from the 300 Area buried waste test facility, Grass Site, and 200 East Area closed-bottom deep lysimeter. Information in the report includes a description of the methods used to estimate groundwater recharge, overview of the water-balance study at Hanford, summarize water-balance components and recharge estimates, and discuss implications to contaminant transport.

\section{Rockhold M.L., M.J. Fayer, and P.R. Heller. 1993. Physical and Hydraulic Properties of Sediments and Engineered Materials Associated with Grouted Double-Shell Tank Waste Disposal at Hanford. PNL-8813, Pacific Northwest Laboratory, Richland, Washington.}

This report outlines the procedures used for data collection and analyses to obtain physical and hydraulic property estimates for sediment samples and engineered materials associated with grouted double-shell tank waste disposal at Hanford. The data parameter estimates that are contained in this report were generated in support of unsaturated flow and contaminant transport modeling studies and sensitivity analyses of the grout performance assessment. The emphasis of this report is on sediment samples from characterization well 299-E25-234, which is located within the boundaries of the Grout Treatment Facility. The facility is located just outside of the eastern boundary of the 200 East Area. Estimates of water retention parameters and saturated hydraulic conductivity data are provided sediment samples from well 299-W25-234 and for samples from several other locations in the 200 East Area. These data and parameter estimates are used to estimate average ranges of variability that are assumed to be representative of the sediment underlying the Grout Treatment Facility. Data and parameter estimates are also provided for most of the material comprising the engineered part of the grout waste isolation system. These materials include grout, cement, gravel, and the RCRA clay cap.

82. Rockhold M.L., R.E. Rossi, R.G. Hills, and G.W. Gee. 1994. "Similar Media Scaling and Geostatistical Analysis of Soil Hydraulic Properties." In 33rd Hanford Science Symposium on In-Situ Remediation, eds. G.W. Gee and N.R. Wing, pp. 1099-1131. Battelle Press, Columbus, Ohio.

\section{Rockhold M.L., M.J. Fayer, G.W. Gee, and C.T. Kincaid. 1995. Estimation of Natural Ground Water Recharge for the Performance Assessment of a Low-Level Waste Disposal Facility at the Hanford Site. PNL-10508, Pacific Northwest Laboratory, Richland, Washington.}

In 1994, Pacific Northwest Laboratory (PNL) initiated the Recharge Task, under the PNL Vitrification Technology Development project, to assist Westinghouse Hanford Company in designing and assessing the performance of a low-level waste disposal facility for the U.S. Department of Energy. The Recharge Task was established to address the issue of groundwater recharge in and around the low-level waste facility and throughout the Hanford Site as it affects the unconfined aquifer under the facility. The objectives of this report are to summarize the current knowledge of natural groundwater recharge at the Hanford Site and to outline the work that must be completed in order to provide defensible estimates of recharge for use in the performance assessment of this low-level waste facility. Recharge studies at the 
Hanford Site indicate that recharge rates are highly variable, ranging from nearly zero to greater than $100 \mathrm{~mm} / \mathrm{yr}$, depending on precipitation, vegetation cover, and soil type. Information in this report includes site maps of recharge, vegetation cover, and soil type over the Hanford Site.

84. Rockhold M.L., C.S. Simmons, and M.J. Fayer. 1997. "An analytical solution technique for one-dimensional steady water flow in layered soils." Water Resour. Res. 33:897-902.

85. Rockhold M.L., C.J. Murray, and M.J. Fayer. 1998. "Conditional simulation and upscaling of soil hydraulic properties." In: International Workshop, Characterization and Measurement of the Hydraulic Properties of Unsaturated Porous Media, van Genuchten, Leij, Wu, eds., October 22-24, 1997, University of California, Riverside California.

86. Rohay V.J., G.W. Last, V.L. King, L.A. Doremus, and D.C. Lanigan. 1992. FY92 Site Characterization Status Report and Data Package for the Carbon Tetrachloride Site. WHC-SD-EN-TI-063, Westinghouse Hanford Company, Richland, Washington.

This report provides that status and accomplishments from fiscal year 1992 site characterization activities conducted as part of the 200 West Area carbon tetrachloride expedited response action and the volatile organic compounds - arid integrated demonstration. During fiscal year 1992, these programs focused on the carbon tetrachloride plume in the unsaturated zone underlying the 200 West Area at the Hanford Site. Field data collected at the site includes moisture profiles at five wells. Laboratory measurements of unsaturated hydraulic conductivity versus water content by the centrifuge method are also available.

87. Rohay V.J., K.J. Swett, V.M. Johnson, G.W. Last, D.C. Lanigan, and L.A. Doremus. 1993. FY93 Site Characterization Status Report and Data Package for the Carbon Tetrachloride Site. WHC-SD-EN-TI-202 Rev. 0, Westinghouse Hanford Company, Richland, Washington.

This report provides that status and accomplishments from fiscal year 1993 site characterization activities conducted as part of the 200 West Area carbon tetrachloride expedited response action and the volatile organic compounds - arid integrated demonstration. During fiscal year 1993, these programs focused on the carbon tetrachloride plume in the unsaturated zone underlying the 200 West Area at the Hanford Site. Data collected during fiscal year 1993 includes moisture retention data, particle size distribution, soil bulk density, air permeability measurements, and saturated hydraulic conductivity.

88. Rohay V.J. 1995. FY93 Wellfield Enhancement Status Report and Data Package for the 200 West Area Carbon Tetrachloride Expedited Response Action. BHI-00105, Bechtel Hanford Inc., Richland, Washington.

This report provides a status and results from fiscal year 1993 well-field enhancement activities conducted as part of the 200 West Area carbon tetrachloride expedited response action. The purpose of the well-field enhancement activities is to optimize removal of the carbon tetrachloride from the unsaturated zone. Four new extraction wells, each with two screened intervals, were installed as part of the expedited 
response action fiscal year 1993 well-field activities. Three additional wells were drilled with single screen intervals. Data available from this study includes borehole moisture profiles, air permeability measurements, and particle-size distributions.

89. Routson R.C. and K.R. Fecht. 1979. Soil (Sediment) Properties of Twelve Hanford Wells with Geologic Interpretation. RHO-LD-82, Rockwell Hanford Operations, Richland, Washington.

Laboratory soil (sediment) properties were determined for twelve study wells from an area south of the Hanford 200 West Area. Properties measured include 1) mechanical analysis, 2) porosity, 3) CaCO3 content, 4) moisture content at $0.33,1.5$, and 15 bars water potential, 5) field moisture content, 6) cation exchange capacity, and 7) bulk density.

90. Shields K.D. 1995. Comparison of Soil Physical Properties for Carbon Tetrachloride and Water Using the UFA Method. Masters Thesis, Washington State University, Richland, Washington.

This study compared the matric potential, the unsaturated hydraulic conductivity, and gas conductivity of four soils with respect to water and carbon tetrachloride as a function of fluid content. This study used a centrifuge device (unsaturated flow apparatus) to derive the unsaturated hydraulic conductivity and gas conductivity values. Three soil samples from the volatile organic carbon site are used in this study.

\section{Sisson J.B. and A.H. Lu. 1984. Field Calibration of Computer Models for Application to Buried Liquid Discharges: A Status Report. RHO-ST-46, Rockwell Hanford Operations, Richland, Washington.}

This report documents the design, construction, operation, and measurements at the 200 East Area, injection test site. The site consists of 32 vadose wells completed to a depth of 18 meters, arranged in eight concentric rings about a central injection well completed to a depth of 5 meters. Ten fluid injections were conducted between September 22, 1980 through November 24, 1980. Each injection event was spaced one week apart and consisted of a 4,000 liter pulse. The migration and spread of the moisture plume was monitored at the 32 vadose wells by neutron probe. Radionuclide traces were also released during these injection intervals. In addition to the field measurements, a two-dimensional numerical flow simulation was created for the site. The simulation results showed good agreement with the measured distributions.

92. Smoot J.L., J.E. Szecsody, B. Sagar, G.W. Gee, and C.T. Kincaid. 1989. Simulations of Infiltration of Meteoric Water and Contaminant Plume Movement in the Vadose Zone at Single-Shell Tank 241-T-106 at the Hanford Site. WHC-EP-0332, Westinghouse Hanford Company, Richland, Washington.

This report documents a simulation of the 241-T-106 tank leak that occurred during 1973. The document includes precipitation and evaporation information used to determine the recharge rate to the vadose, the conceptual model of the system, a discussion of the model design and components, and hydraulic and physical data for the system. One appendix includes laboratory results for water retention, bulk density, and sieve analysis of sample collected at AP tank farms. 
93. Tyler S.W., B.R. Scanlon, G.W. Gee, and G.B. Allison. 1999. "Water and Solute Transport in Arid Vadose Zones: Innovations in Measurement and Analysis." In Vadose Zone Hydrology, eds. M.B. Parlange and J.W. Hopmans, pp. 334-373. Oxford Press, New York

94. Valenta M.M., M.B. Martin, D.G. Horton, J.R. Moreno, R.E. Ferri, and S.P. Reidel. 2000. Particle Size Distribution Data from Existing Boreholes at the Immobilized Low-Activity Waste Site. PNNL-13328, Pacific Northwest National Laboratory, Richland, Washington.

This report lists the sieve analysis for seventy-nine sediment samples from four boreholes near the immobilized low-activity waste site. These data indicate that the particle size of the sediment is consistent across the waste site and is dominated by sand in the upper part of the Hanford formation with more gravel rich units in the lower part.

95. Vermeul V.R., S.S. Teel, J.E. Amonette, C.R. Cole, J.S. Fruchter, Y.A. Gorby, F.A. Spane, J.E. Szecsody, M.D. Williams, and S.B. Yabusaki. 1995. Geologic, Geochemical, Microbiologic, and Hydrologic Characterization at the In Situ Manipulation Test Site. PNL-10633, Pacific Northwest Laboratory, Richland, Washington.

This report documents results from characterization activities at the in situ redox manipulation field test site that is located within the 100-HR-3 Operable Unit at Hanford. Information obtained during hydrogeologic characterization of the site include sediment physical properties, geochemical properties, microbiological population data, and aquifer hydraulic properties. Sediment physical properties include in situ moisture content, sieve, particle density, bulk density, and porosity.

96. Ward A.L., G.W. Gee, and S.O. Link. 1997. Hanford Prototype-Barrier Status Report: FY 1997. PNNL-11789, Pacific Northwest National Laboratory, Richland, Washington.

This report describes the design and construction of the prototype surface barrier and experimental data collected at the site from 1994 through 1997. Experiments were performed to simulate a 2000-year precipitation event for each of the years of the study. A variety of surface vegetation was also added to determine the effect of evapotranspiration on water storage as well as assess potential root intrusion into the cover material. The potential for wind erosion was also tested for the cover. Information derived from the site includes soil water storage, drainage, soil moisture profiles, precipitation/irrigation history, and physical properties of the barrier materials. The ultimate goal of this study was to evaluate water balance at the site. Monitoring stations at the site include neutron and capacitance probe access tubes, TDR, a precipitation meter, heat dissipation units, wind monitoring stations, a water erosion flume, creep gauges, and settlement station.

97. Ward A.L. and G.W. Gee. 1997. "Performance and Water Balance Evaluation of a Field-Scale Surface Barrier." J. Environ. Qual. 26: 694-705.

98. Waugh W.J., M.E. Thiede, D.J. Bates, L.L. Cadwell, G.W. Gee, and C.J. Kemp. 1994. "Plant Establishment and Water Storage in Soil-Gravel Admixtures.” J. Environ. Quality 23:676-685. 
99. Weeks D.C. and J.V. Borghese. 1994. Site Characterization Report for the Environmental Restoration Disposal Facility. WHC-SD-EN-ER-005 REV. 0, Westinghouse Hanford Company, Richland, Washington.

This report documents the geologic and hydrologic characterization of the subsurface beneath the ERDF site. Included in this report are laboratory-derived data collected from boreholes drilled at the ERDF site. Information from these boreholes includes water retention, sieve analysis, and bulk density.

100. Westinghouse Hanford Company. 1986. Geotechnical Engineering Procedures Manual. WHC-IP-0635, Westinghouse Hanford Company, Richland, Washington.

This manual provides the technical procedures and guidance necessary to perform and document Environmental Technology Group work in a technically sound, safe, and defensible manner. This manual is subordinate to WHC-CM-7-7, Environmental Investigations and Site Characterization Manual. This manual is used to provide administrative and technical control of work conducted by the Environmental Technology Group in support of site characterization; assessment; remediation; and closure technology, development, demonstration, testing, evaluation, and applications.

101. White M.D. and M. Oostrom. 1996. STOMP Subsurface Transport Over Multiple Phase: User' Guide. PNNL-11216, Pacific Northwest National Laboratory, Richland, Washington.

The STOMP simulator solves the partial-differential equation. The simulator has been written with a variable source code that allows the user to choose the solved governing equations (e.g., water mass, air mass, dissolved-oil mass, oil mass, salt mass, thermal energy). Depending on the chosen operational mode, the governing transport equations will be written over one to four phases (e.g., aqueous phase, gas phase, nonaqueous phase liquid [NAPL] phase, ice phase, solid phase). Solute transport, radioactive decay, and first-order chemical reactions are solved using a direct solution technique. Input is directed through semi-formatted text files and output is available through a variety of user-directed formats. The simulator recognizes a number of boundary condition types and allows their specification both internally and externally to the computational domain.

102. Wright J., J.L. Conca, and X. Chen. 1994. Hydrostratigraphy and Recharge Distributions from Direct Measurement of Hydraulic Conductivity Using the UFA Method. PNL-9424, Pacific Northwest Laboratory, Richland, Washington.

The unsaturated flow apparatus is a centrifugation device that is used to measure unsaturated hydraulic conductivity, diffusion coefficients, and retardation factors. This method achieves steady-state conditions in minutes to hours, where conventional methods can take weeks to months and cannot provide data at the very low water contents that are achieved with this method. From 8 to 14 measurements of hydraulic conductivity, which describes the rate at which fluids move through soil as a function of decreasing volumetric water content, were made on each of approximately 50 arid soil and sediment samples from former waste disposal sites at Hanford, Washington. Information in this report includes water content versus unsaturated hydraulic conductivity, particle size distribution, and mineralogical composition. 
103. Barnett, B. R., G. W. Gee, and M. D. Sweeney. 2001. Test Plan for the Demonstration of Geophysical Techniques for Single-Shell Tank Leak Detection at the Hanford Mock Tank Site: Fiscal Year 2001. PNNL-13598. Pacific Northwest National Laboratory, Richland, Washington.

104. Barnett, B. R., G. W. Gee, and M. D. Sweeney. 2002. Results of Tank Leak Detection Demonstration using Geophysical Techniques at the Hanford Mock Tank Site- Fiscal Year 2001. PNNL-13818. Pacific Northwest National Laboratory, Richland, Washington.

105. Barnett, D. B., G. W. Gee, and M. D. Sweeney. 2002. Tank Leak Detection Demonstration at the Hanford Site, Washington, 2001, Using Geophysical Techniques. 7 pp $9^{\text {th }}$ Biennial International Conference on Nuclear and Hazardous Waste Management, Spectrum 2002, Aug. 4-8, 2002, Reno, Nevada. American Nuclear Society., La Grange Park, Illinois.

106. Cadwell, L. L., S. O. Link, and G. W. Gee. 1993. Hanford Site Permanent Isolation Surface Barrier Development Program: Fiscal Year 1992 and 1993 Highlights. PNL-8741, Pacific Northwest Laboratory, Richland, Washington.

107. Campbell, M. D., and G. W. Gee. 1990. Field Lysimeter Test Facility: Third year (FY 1990) Test Results. PNL-7558, Pacific Northwest Laboratory, Richland, Washington.

108. Fayer, M. J., W. Conbere, P. R. Heller, and G. W. Gee. 1985. Model Assessment of Protective Barrier Designs. PNL-5604, Pacific Northwest Laboratory, Richland, Washington.

109. Fayer M.J. and G.W. Gee. 1997. "Hydrologic Model Tests for Landfill Covers Using Field Data." p 53-68. In T.D. Reynolds and R.C. Morris (eds). Landfill Capping in the Semi-Arid West, Conference Proceedings. Jackson Lake, Wyoming. May 1997, Environmental Science and Research Foundation, Idaho Falls, Idaho.

110. Gee, G. W. 1987. Recharge at the Hanford Site: Status Report. PNL-6403, Pacific Northwest Laboratory, Richland, Washington.

111. Gee, G. W., and D. Hillel. 1988. "Groundwater Recharge in Arid Regions: Review and Critique of Estimation Methods." J. Hydrol. Process. 2:255-266.

112. Gee, G. W., C. T. Kincaid, R. J. Lenhard, and C. S. Simmons. 1991. "Recent Studies of Flow and Transport in the Vadose Zone." Rev. Geophys. 29 (2):227-239.

113. Gee, G. W., L. L. Cadwell, H. D. Freeman, M. W. Ligotke, S. O. Link, R. A. Romine, and W. H. Walters, Jr. 1993. Testing and Monitoring Plan for the Permanent Isolation Surface Barrier Prototype. PNL-8391, Pacific Northwest Laboratory, Richland, Washington.

114. Gee, G. W., D. Felmy, J. C. Ritter, M. D. Campbell, J. L. Downs, M. J. Fayer, R. R. Kirkham, and S. O. Link. 1993. Field Lysimeter Test Facility: Status Report IV: FY 1993. PNL-8911, Pacific Northwest Laboratory, Richland, Washington. 
115. Gee G.W., A.L. Ward, B.G. Gilmore, M.W. Ligotke, and S.O. Link. 1995. Hanford PrototypeBarrier Status Report: FY 1995. PNL-10872, Pacific Northwest Laboratory. Richland, Washington.

116. Gee, G. W., A. L. Ward, B. G. Gilmore, M. W. Ligotke, and S. O. Link. 1995. Hanford Prototype Surface Barrier Status Report: FY 1995. PNL-10872, Pacific Northwest Laboratory, Richland, Washington.

117. Gee, G. W., A. L. Ward, B. G. Gilmore, S. O. Link, G. W. Dennis, and T. K. O ' Neil. 1996. Hanford Prototype Barrier Status Report: FY 1996. PNL 11367, Pacific Northwest National Laboratory, Richland, Washington.

118. Gee G.W. and A.L. Ward. 1997. "Still in Quest for the Perfect Cap." P. 145-164. In T.D. Reynolds and R.C. Morris (eds). Landfill Capping in the Semi-Arid West, Conference Proceedings. Jackson Lake, Wyoming. May 1997, Environmental Science and Research Foundation, Idaho Falls, Idaho.

119. Gee G.W., A.L. Ward, and M.J. Fayer. 1997. "Surface Barrier Research at the Hanford Site." Land Contamination and Reclamation. 5(3):233-237.

120. Gee G.W., N.R. Wing, and A.L. Ward. 1997. "Development and Testing of Permanent Isolation Surface Barriers at the Hanford Site.” p. D3-D22. In Barrier Technologies for Environmental Management. National Academy Press, Washington. D.C.

121. Gee G.W., A.L. Ward, B.G. Gilmore, S.O. Link, G.W. Dennis, and T.K. O'Neil. 1996. Hanford Prototype-Barrier Status Report: FY 1996. PNNL-11367, Pacific Northwest National Laboratory. Richland, Washington.

122. Gee G.W. and A.L. Ward. 2001. Vadose Zone Transport Field Study: Status Report. PNNL13679, Pacific Northwest National Laboratory, Richland, Washington.

123. Gee, GW, AL Ward, JC Ritter, JB Sisson, JM Hubbell, H Sydnor. 2001. Installation of a Hydrologic Characterization Network for Vadose Zone Monitoring of a Single-Shell Tank Farm at the U. S. Department of Energy Hanford Site. PNNL-13712, Pacific Northwest National Laboratory, Richland, Washington.

124. Gee, G. W., A. L. Ward, T. G. Caldwell, and J. C. Ritter. 2002. "A vadose-zone water flux meter with divergence control”, Water Resour. Res.38 (8); 10.1029/2001WR00816, 2002.

125. Gee, G. W., A. L. Ward, Z. F. Zhang, G. S. Campbell, and J. Mathison. 2002. "The influence of hydraulic non-equilibrium on pressure plate data." Vadose Zone J. 1:172-178.

126. Gee, G. W., and A. L. Ward. 2002. Predicting deep drainage using soil hydraulic properties and soil texture data. $9 \mathrm{pp}$. In Transaction of the $17^{\text {th }}$ World Congress of Soil Science. Bangkok, Thailand, August 2002 (electronic). 
127. Gee, G. W. and D. Or. 2002. "Particle-size analysis". In Ch 2. Methods of Soil Analysis, Part 1. J. Dane and C. Topp (eds.). Soil Sci. Soc. Am., Madison, Wisconsin ( in press-Sept. 2002).

128. Gee, G. W. and A. L. Ward. 2002. Vadose Zone Field Experiments and Recharge Estimates for the S-SX Tank Farm. Appendix D.8 - S-SX Tank Farm Field Investigation Report.

129. Gee, G. W. and A. L. Ward. 2002. "Vapor transport in dry soils". Encyclopedia of Water Science, Marcel Dekker (in press).

130. Hunt A.G. 2001. "Application of Percolation Theory to Porous Media with Distributed Local Conductances." Adv. Water Resour. 24:279-307.

131. Hunt A.G and G.W. Gee. 2002. "Application of Critical Path Analysis to Fractal Porous Media: Comparison with Examples from the Hanford Site.” Adv. Water Resour. 25(1):129-146.

132. Hunt, A. G., and G. W. Gee. 2002. "Water-retention estimates using continuum percolation theory: Test of Hanford Site soils". Vadose Zone J. (in press-Nov. issue).

133. Jones, T. L, G. W. Gee, R. R. Kirkham, and D. D. Gibson. 1982. The Measurement of Water Potential in Low-Level Waste Management. PNL-4388, Pacific Northwest Laboratory, Richland, Washington.

134. Last G.V., T.D. Caldwell, and A.T. Owen. 2001. Sampling of Boreholes WL-3A through-12 in Support of the Vadose Zone Transport Field Study. PNNL-13631, Pacific Northwest National Laboratory. Richland, Washington.

135. Last G.V. and T.D. Caldwell. 2001. Core Sampling in Support of the Vadose Zone Transport Field Study. PNNL-13454, Pacific Northwest National Laboratory, Richland, Washington.

136. Link, S. O., L. L. Cadwell, C. A. Brandt, J. L. Downs, R. E. Rossi, and G. W. Gee. 1994. Biointrusion Test Plan for the Permanent Isolation Surface Barrier Prototype. PNL-9411, Pacific Northwest Laboratory, Richland, Washington.

137. Link S.O., N.R. Wing, and G.W. Gee. 1995. The Development of Permanent Isolation Barriers for Buried Wastes in Cold Deserts: Hanford Washington." J. Arid Lands Studies 4:215224.

138. Meyer P. D., M. L. Rockhold, W. E. Nichols, and G. W. Gee. 1996. Hydrologic Evaluation Methodology for Estimating Water Movement through the Unsaturated Zone at Commercial LowLevel Radioactive Waste Disposal Sites. NUREG/CR-6346, U. S. Nuclear Regulatory Commission, Washington, D. C.

139. Myers, D.R. 1985. Diposal Materials Study. RHO-WM-EV-12-P, Rockwell Hanford Operations, Richland, Washington. 
140. Petersen, K. L., S. O. Link, and G. W. Gee (eds.). 1995. Hanford Site Long-Term Surface Barrier Development Program: Fiscal Year 1994 Highlights. PNL 10605, Pacific Northwest Laboratory, Richland, Washington.

141. Sackschewsky M.R., C.J. Kemp, S.O. Link, and W.J. Waugh. 1995. "Soil Water Balance Changes in Engineered Soil Surfaces.” J. Environ. Qual. 24:352-359.

142. Serne, R. J., H. T. Schaef, B. N. Bjornstad, D. C. Lanigan, G. W. Gee, C. W. Lindenmeier, R. E. Clayton, V.L. LeGore, R. D. Orr, M. J. O'Hara, C. F. Brown, G. V. Last, D. S. Burke, T. C. Wilson, and B. A. Williams. 2002. Characterization of Vadose Zone Sediment: Borehole 299-W2319 [SX-115] in the S-SX Waste Management Area: PNNL-13757-2 (electronic). Pacific Northwest National Laboratory, Richland, Washington.

143. Sisson, J. B., G. W. Gee, J. M. Hubbell, W. L. Bratton, J. C. Ritter, A. L. Ward, and T. G. Caldwell. 2002. "Advances in tensiometry for long-term monitoring of capillary pressures". Vadose Zone J. (in press-Nov. issue).

144. Smyth, J. D., E. Bresler, G. W. Gee, and C. T. Kincaid. 1990. Development of an Infiltration Evaluation Methodology for Low-Level Waste Shallow Land Burial Sites. NUREG/CR-5523, U.S. Nuclear Regulatory Commission, Washington, D.C.

145. U.S. Department of Energy. 1999. 200-BP-1 Prototype Barrier Treatability Test Report. DOE/RL-99-11. U.S. Department of Energy, Richland, Washington.

146. Walter, M. B., M. J. Graham, and G. W. Gee. 1984. A Field Lysimeter Facility for Evaluating the Performance of Commercial Solidified Low-Level Waste. PNL-5253, Pacific Northwest Laboratory, Richland, Washington.

147. Ward A.L., G.W. Gee, and S.O. Link. 1997. Hanford Prototype-Barrier Status Report: FY 1997. PNNL-11789. Pacific Northwest National Laboratory. Richland, Washington.

148. Ward, A. L., G. W. Gee, and M. D. White. 1997. A Comprehensive Analysis of Contaminant Transport in the Vadose Zone Beneath Tank SX-109. PNNL-11463, Pacific Northwest National Laboratory, Richland, Washington.

149. Ward, A. L., and G. W. Gee. 2000. "Hanford Site Surface Barrier Technology." In Vadose Zone Science Technology and Solutions, pp. 1414-1423. U. S. Department of Energy, Battelle Press, Columbus, Ohio.

150. Ward A.L. and G.W. Gee. 2000. Vadose Zone Transport Field Study: Detailed Test Plan for Simulated Leak Tests. PNNL-13263, Pacific Northwest National Laboratory, Richland, Washington. 
151. Ward A.L. and G.W. Gee. 2001. Vadose Zone Transport Field Study: FY 2001 Test Plan. PNNL-13451, Pacific Northwest National Laboratory, Richland, Washington.

152. Ward A.L. and G.W. Gee. 2001. Vadose Zone Transport Field Study: FY 2002 Test Plan. PNNL-13587. Pacific Northwest National Laboratory, Richland, Washington.

153. Ward, A. L., G. W. Gee and Z. F. Zhang. 2002. Hydrologic Tests of Lateral Flow and Transport in the Hanford Vadose Zone. Appendix D.6, In. B-BY BX. Field Investigation Report. Flour Hanford Group, Richland, Washington.

154. Wierenga, P. J., M. H. Young, G. W. Gee, R. G. Hills, C. T. Kincaid, T. J. Nicholson, and R. E. Cady. 1993. Soil Characterization Methods for Unsaturated Low-Level Waste Sites. NUREG/CR5988, U.S. Nuclear Regulatory Commission, Washington D.C.

155. Wing, N. R., and G. W. Gee (eds). 1990. Hanford Site Protective Barrier Development Program. Fiscal Year 1989 Highlights. WHC-EP-0318, Westinghouse Hanford Company, Richland, Washington.

156. Wing N.R., F.M. Corpuz, K.L. Peterson, and A.M. Tallman. 1995. Physical Stability of LongTerm Surface Barriers-Assessment of Potentially Disruptive Events. BHI-00145, Bechtel Hanford Inc., Richland, Washington.

157. Wing N.R., K.L. Petersen, C. Whitlock, and R.L. Burk. 1995. Long-Term Climate Change Effects Task for the Hanford Permanent Isolation Barrier Development Program: Final Report. BHI00144. Bechtel Hanford Inc. Richland, Washington.

158. Wittreich C.D. and C.R. Wilson. 1991. "Lysimeters for Evapotransiration and Environmental Measurements." Proceedings from the International Symposium of Lysimetry. American Society of Civil Engineers, Honolulu, Hawaii.

159. Zhang, Z. F., A. L. Ward and G. W. Gee. 2002. A Parameter Scaling Concept for Estimating Field-Scale Hydraulic Functions of Layered Soils pp. 103-107. In A. N Findkakis (ed.) Proceedings of the 2002 International Groundwater Symposium, Lawrence Berkeley National Laboratory, Berkeley, California, March 2002.

160. Zhang, Z. F., A. L. Ward, and G. W. Gee. 2002. Estimating soil hydraulic parameters of a field drainage experiment using inverse techniques. Vadose Zone J. (in press- Nov. issue). 


\section{Appendix C}

Table of Hanford Sites and Soil Physics Measurements 


\section{Appendix C}

\section{Table of Hanford Sites and Soil Physics Measurements}

This appendix contains a list of the Hanford sites and the types of data collected at each site. The list is in a spreadsheet format and is organized hierarchically by area, site name, and well number/site type, in that order. There are five areas listed, 100, 200 East, 200 West, 300, and 600. The site name is a subregion within the area and is typically a descriptive name related to the program that funded the work. The well number is a Hanford Site descriptive identifier with 199 representative of a 100 Area well, 299-EXX-XXX and 299-WXX-XXX representing wells in the 200 East and 200 West Areas, respectively. The X's are placeholders for numerals that signify a Hanford coordinate location.

The prefixes, 399 and 699, signify the 300 and 600 Areas, respectively. Data in the records are represented as a numeral or the letter "Y." The numeral is used for laboratory data and identifies how many individual sediment samples were tested for the property listed at the top of the column. For most cases, each sample represents a sediment core from a discrete depth, which was subjected to a number of tests in the lab. The "Y" signifies that a measurement in the category is available. This was typically used to identify in situ sampling at field sites. At these sites, multiple measurements were typically made along an access tube. Rather than count each measurement or each sampling event, it was simply acknowledged that data in the category is available at the site.

Laboratory data included in the table are water retention curves, bulk or particle density, saturated hydraulic conductivity, and unsaturated hydraulic conductivity. In situ field measurements include neutron probe, soil water drainage, soil water storage, soil water moisture profile, and air permeability. The final column lists references for each of the sites. References are either publications or, where no publications are available, the initials of a contact person named from the "Hanford soil physics users community." The initials typically seen in the spreadsheet are RK and EJF that represent Raz Khaleel and Eugene Freeman, respectively. The publication year is used to reference publications. However, the publications in the bibliography (Appendix B) are listed alphabetically by author rather than by publication year. Appendix D lists the publication year in descending order with the accompanying authors list and publication identifier. The way to use the references in this appendix is to look up the publication number in Appendix D, read off the lead authors name in this appendix, and look up the publication in Appendix B, which is sorted alphabetically by lead author. 


\begin{tabular}{|c|c|c|c|c|c|c|c|c|c|c|c|c|c|}
\hline \multirow[b]{2}{*}{ Area } & \multirow[b]{2}{*}{ Site } & \multirow[b]{2}{*}{ Well ID } & \multirow[b]{2}{*}{ Sieve } & \multicolumn{2}{|c|}{ Laboratory Derived Data } & \multirow{2}{*}{$\begin{array}{l}\text { Unsat. } \\
\text { Cond. }\end{array}$} & \multirow{2}{*}{$\begin{array}{l}\text { Sat. } \\
\text { Cond. }\end{array}$} & \multirow{2}{*}{ Neutron } & \multirow{2}{*}{$\begin{array}{l}\text { Water } \\
\text { Storage }\end{array}$} & \multicolumn{2}{|c|}{ Field Derived Data } & \multirow{2}{*}{ Air } & \multirow[b]{2}{*}{ Reference/Contact } \\
\hline & & & & Bulk/Part Density & Moisture & & & & & Drainage & Moisture Profile & & \\
\hline 100 & BC-1 & 116-B-1 & 2 & 2 & 2 & & & & & & & & EJF,RK \\
\hline 100 & BC-5 & 199-B2-12 & 3 & 3 & 3 & & & & & & & & HNF-4769, EJF, RK \\
\hline 100 & BC-5 & 199-B4-9 & 4 & 4 & 4 & 3 & 3 & & & & & & EJF,RK \\
\hline 100 & BC-5 & 199-B9-2 & 4 & 4 & 4 & 2 & 2 & & & & & & EJF,RK \\
\hline 100 & DR-1 & 116-DR-1 & 3 & 3 & 3 & 3 & 3 & & & & & & EJF, RK \\
\hline 100 & DR-2 & 199-D5-30 & 2 & 2 & 2 & 2 & 2 & & & & & & EJF, RK \\
\hline 100 & FR-1 & $116-F-14$ & 4 & 4 & 4 & 4 & 4 & & & & & & EJF, RK \\
\hline 100 & FR-3 & 199-F5-43 & 2 & 2 & 2 & 2 & 2 & & & & & & EJF, RK \\
\hline 100 & FR-3 & 199-F5-43E & 1 & 1 & 1 & & & & & & & & EJF, RK \\
\hline 100 & FR-3 & 199-F5-48 & 3 & 3 & 3 & 3 & 3 & & & & & & EJF, RK \\
\hline 100 & FR-3 & 199-F8-3 & 3 & 3 & 3 & 2 & 2 & & & & & & EJF, RK \\
\hline 100 & HR-1 & $116-\mathrm{H}-1$ & 3 & 3 & 3 & 1 & 1 & & & & & & EJF,RK \\
\hline 100 & HR-3 & 199-D5-14 & 3 & 3 & 3 & & & & & & & & HNF-4769, EJF, RK \\
\hline 100 & HR-3 & 199-D5-17 & 4 & 4 & 4 & & & & & & & & HNF-4769, EJF, RK \\
\hline 100 & HR-3 & 199-D8-53 & 1 & 1 & 1 & & & & & & & & HNF-4769, EJF, RK \\
\hline 100 & HR-3 & 199-D8-54A & 1 & 1 & 1 & & & & & & & & HNF-4769, EJF, RK \\
\hline 100 & HR-3 & 199-D8-54B & 4 & 4 & 4 & & & & & & & & HNF-4769, EJF, RK \\
\hline 100 & HR-3 & 199-D8-55 & 1 & 1 & 1 & & & & & & & & HNF-4769, EJF, RK \\
\hline 100 & HR-3 & 199-H4-45 & 3 & 3 & 3 & & & & & & & & HNF-4769, EJF, RK \\
\hline 100 & HR-3 & 199-H4-46 & 2 & 2 & 2 & & & & & & & & HNF-4769, EJF, RK \\
\hline 100 & HR-3 & 199-H5-1 & 3 & 3 & 3 & & & & & & & & HNF-4769, EJF, RK \\
\hline 100 & HR-3 & 699-93-46 & 3 & 3 & 3 & & & & & & & & EJF, RK \\
\hline 100 & H-basin & 199-H3-2A & & & 7 & & & $\mathrm{Y}$ & & & $\mathrm{Y}$ & & PNL-6728 \\
\hline 100 & H-basin & 199-H3-2B & & & 8 & & & $\mathrm{Y}$ & & & $\mathrm{Y}$ & & PNL-6728 \\
\hline 100 & H-basin & 199-H3-2C & & & 8 & & & $\mathrm{Y}$ & & & $\mathrm{Y}$ & & PNL-6728 \\
\hline 100 & H-basin & 199-H4-7 & & & 8 & & & $\mathrm{Y}$ & & & $\mathrm{Y}$ & & PNL-6728 \\
\hline 100 & H-basin & 199-H4-8 & & & 9 & & & $\mathrm{Y}$ & & & $\mathrm{Y}$ & & PNL-6728 \\
\hline 100 & H-basin & 199-H4-9 & & & 8 & & & $\mathrm{Y}$ & & & $\mathrm{Y}$ & & PNL-6728 \\
\hline 100 & H-basin & 199-H4-10 & & & 6 & & & $\mathrm{Y}$ & & & $\mathrm{Y}$ & & PNL-6728 \\
\hline 100 & H-basin & 199-H4-11 & & & 9 & & & $\mathrm{Y}$ & & & $\mathrm{Y}$ & & PNL-6728 \\
\hline 100 & H-basin & 199-H4-12A & & & 7 & & & $\mathrm{Y}$ & & & $\mathrm{Y}$ & & PNL-6728 \\
\hline 100 & H-basin & 199-H4-12B & & & 7 & & & $\mathrm{Y}$ & & & $\mathrm{Y}$ & & PNL-6728 \\
\hline
\end{tabular}




\begin{tabular}{|c|c|c|c|c|c|c|c|c|c|c|c|c|c|}
\hline \multirow[b]{2}{*}{ Area } & \multirow[b]{2}{*}{ Site } & \multirow[b]{2}{*}{ Well ID } & \multirow[b]{2}{*}{ Sieve } & \multicolumn{2}{|c|}{ Laboratory Derived Data } & \multirow{2}{*}{$\begin{array}{l}\text { Unsat. } \\
\text { Cond. }\end{array}$} & \multirow{2}{*}{\begin{tabular}{|c|} 
Sat. \\
Cond.
\end{tabular}} & \multirow{2}{*}{\begin{tabular}{|l|} 
Neutron \\
\end{tabular}} & \multirow{2}{*}{$\begin{array}{l}\text { Water } \\
\text { Storage }\end{array}$} & \multicolumn{2}{|c|}{ Field Derived Data } & \multirow{2}{*}{$\begin{array}{c}\text { Air } \\
\text { Perm. }\end{array}$} & \multirow[b]{2}{*}{ Reference/Contact } \\
\hline & & & & Bulk/Part Density & Moisture & & & & & Drainage & Moisture Profile & & \\
\hline 100 & H-basin & 199-H4-12C & & & 7 & & & $\mathrm{Y}$ & & & \begin{tabular}{|c|}
$\mathrm{Y}$ \\
\end{tabular} & & PNL-6728 \\
\hline 100 & H-basin & 199-H4-13 & & & 8 & & & $\mathrm{Y}$ & & & $\mathrm{Y}$ & & PNL-6728 \\
\hline 100 & H-basin & 199-H4-14 & & & 8 & & & $\mathrm{Y}$ & & & $\mathrm{Y}$ & & PNL-6728 \\
\hline 100 & H-basin & 199-H4-15A & & & 6 & & & $\mathrm{Y}$ & & & $\mathrm{Y}$ & & PNL-6728 \\
\hline 100 & H-basin & 199-H4-15B & & & 6 & & & $\mathrm{Y}$ & & & $\mathrm{Y}$ & & PNL-6728 \\
\hline 100 & H-basin & 199-H4-15C & & & 6 & & & $\mathrm{Y}$ & & & $\mathrm{Y}$ & & PNL-6728 \\
\hline 100 & H-basin & 199-H4-16 & & & 9 & & & $\mathrm{Y}$ & & & $\mathrm{Y}$ & & PNL-6728 \\
\hline 100 & H-basin & 199-H4-17 & & & 3 & & & $\mathrm{Y}$ & & & $\mathrm{Y}$ & & PNL-6728 \\
\hline 100 & H-basin & 199-H4-18 & & & 2 & & & $\mathrm{Y}$ & & & $\mathrm{Y}$ & & PNL-6728 \\
\hline 100 & $\mathrm{~K}$ & 199-K-109A & 3 & 3 & 3 & 3 & 3 & & & & & & EJF, RK \\
\hline 100 & $\mathrm{~K}$ & 199-K-110A & 2 & 2 & 2 & 2 & 2 & & & & & & EJF, RK \\
\hline 100 & $\mathrm{~K}$ & 199-K-111A & 2 & 2 & 2 & 2 & 2 & & & & & & EJF, RK \\
\hline 100 & KR-1 & 116-KE-4A & 4 & 4 & 4 & 4 & 4 & & & & & & HNF-4769, EJF, RK \\
\hline 100 & KR-4 & $199-\mathrm{K}-33$ & 3 & 3 & 3 & & & & & & & & EJF,RK \\
\hline 100 & KR-4 & 199-K-35 & 3 & 3 & 3 & & & & & & & & EJF,RK \\
\hline 100 & KR-4 & $199-\mathrm{K}-37$ & 4 & 4 & 4 & & & & & & & & EJF,RK \\
\hline 100 & NR-2 & $199-\mathrm{N}-80$ & 4 & 4 & 4 & & & & & & & & EJF,RK \\
\hline $200 \mathrm{E}$ & 200-BP-1 & 216-B-43A & 3 & 3 & 3 & & & & & & & & WHC-SD-EN-TI-019, WHC-SD-EN-TI-054 \\
\hline $200 \mathrm{E}$ & 200-BP-1 & 216-B-49A & 4 & 4 & 4 & & & & & & & & WHC-SD-EN-TI-019, WHC-SD-EN-TI-054 \\
\hline $200 \mathrm{E}$ & 200-BP-1 & 216-B-57A & 3 & 3 & 3 & & & & & & & & WHC-SD-EN-TI-019, WHC-SD-EN-TI-054 \\
\hline $200 \mathrm{E}$ & 200-BP-1 & 216-B-61A & 4 & 4 & 4 & & & & & & & & WHC-SD-EN-TI-019, WHC-SD-EN-TI-054 \\
\hline $200 \mathrm{E}$ & 200-BP-1 & 299-E33-38 & 5 & 6 & 6 & & & & & & & & WHC-SD-EN-TI-019, WHC-SD-EN-TI-054 \\
\hline $200 \mathrm{E}$ & 200-BP-1 & 299-E33-40 & 1 & 1 & 1 & & & & & & & & WHC-SD-EN-TI-019, WHC-SD-EN-TI-054 \\
\hline $200 \mathrm{E}$ & APTANK & N/A & 6 & 6 & 6 & & & & & & & & WHC-EP-0332, WHC-SD-EN-TI-019 \\
\hline $200 \mathrm{E}$ & Grout & 299-E25-234 & 30 & 30 & 30 & & & & & & & & WHC-SD-EN-TI-019, PNL-8813 \\
\hline $200 \mathrm{E}$ & ILAW & 299-E17-21 & 20 & 20 & 20 & 20 & 20 & & & 20 & & $\mathrm{Y}$ & HNF-4769; PNNL-13033, PNNL-13328 \\
\hline $200 \mathrm{E}$ & Prototype barrier & Field site & & $\mathrm{Y}$ & & & & $\mathrm{Y}$ & $\mathrm{Y}$ & $\mathrm{Y}$ & $\mathrm{Y}$ & & PNL-10275;PNNL-11789 \\
\hline $200 \mathrm{E}$ & Sisson-Lu & 299-E24-100 & & & & & & 1 & & & & & RHO-ST-46; PNL-10860 \\
\hline $200 \mathrm{E}$ & Sisson-Lu & 299-E24-101 & & & & & & 1 & & & & & RHO-ST-46; PNL-10860 \\
\hline $200 \mathrm{E}$ & Sisson-Lu & 299-E24-102 & & & & & & 1 & & & & & RHO-ST-46; PNL-10860 \\
\hline $200 \mathrm{E}$ & Sisson-Lu & 299-E24-103 & & & & & & 1 & & & & & RHO-ST-46; PNL-10860 \\
\hline $200 \mathrm{E}$ & Sisson-Lu & 299-E24-104 & & & & & & 1 & & & & & RHO-ST-46; PNL-10860 \\
\hline
\end{tabular}




\begin{tabular}{|c|c|c|c|c|c|c|c|c|c|c|c|c|c|}
\hline \multirow[b]{2}{*}{ Area } & \multirow[b]{2}{*}{ Site } & \multirow[b]{2}{*}{ Well ID } & \multirow[b]{2}{*}{ Sieve } & \multicolumn{2}{|c|}{ Laboratory Derived Data } & \multirow{2}{*}{$\begin{array}{l}\text { Unsat. } \\
\text { Cond. }\end{array}$} & \multirow{2}{*}{\begin{tabular}{|c|} 
Sat. \\
Cond.
\end{tabular}} & \multirow[b]{2}{*}{ Neutron } & \multirow{2}{*}{$\begin{array}{c}\text { Water } \\
\text { Storage }\end{array}$} & \multicolumn{2}{|c|}{ Field Derived Data } & \multirow{2}{*}{ Air } & \multirow[b]{2}{*}{ Reference/Contact } \\
\hline & & & & Bulk/Part Density & Moisture & & & & & Drainage & Moisture Profile & & \\
\hline $200 \mathrm{E}$ & Sisson-Lu & 299-E24-105 & & & & & & 2 & & & & & RHO-ST-46; PNL-10860 \\
\hline $200 \mathrm{E}$ & Sisson-Lu & 299-E24-106 & & & & & & 2 & & & & & RHO-ST-46; PNL-10860 \\
\hline $200 \mathrm{E}$ & Sisson-Lu & 299-E24-107 & & & & & & 1 & & & & & RHO-ST-46; PNL-10860 \\
\hline $200 \mathrm{E}$ & Sisson-Lu & 299-E24-76 & & & & & & 1 & & & & & RHO-ST-46; PNL-10860 \\
\hline $200 \mathrm{E}$ & Sisson-Lu & 299-E24-77 & & & & & & 1 & & & & & RHO-ST-46; PNL-10860 \\
\hline $200 \mathrm{E}$ & Sisson-Lu & 299-E24-78 & & & & & & 1 & & & & & RHO-ST-46; PNL-10860 \\
\hline $200 \mathrm{E}$ & Sisson-Lu & 299-E24-79 & 8 & 8 & 8 & 7 & 7 & 2 & & & & & RHO-ST-46; PNL-10860 \\
\hline $200 \mathrm{E}$ & Sisson-Lu & 299-E24-80 & & & & & & 1 & & & & & RHO-ST-46; PNL-10860 \\
\hline $200 \mathrm{E}$ & Sisson-Lu & 299-E24-81 & & & & & & 1 & & & & & RHO-ST-46; PNL-10860 \\
\hline $200 \mathrm{E}$ & Sisson-Lu & 299-E24-82 & & & & & & 1 & & & & & RHO-ST-46; PNL-10860 \\
\hline $200 \mathrm{E}$ & Sisson-Lu & 299-E24-83 & & & & & & 1 & & & & & RHO-ST-46; PNL-10860 \\
\hline $200 \mathrm{E}$ & Sisson-Lu & 299-E24-84 & & & & & & 1 & & & & & RHO-ST-46; PNL-10860 \\
\hline $200 \mathrm{E}$ & Sisson-Lu & 299-E24-85 & & & & & & 1 & & & & & RHO-ST-46; PNL-10860 \\
\hline $200 \mathrm{E}$ & Sisson-Lu & 299-E24-86 & & & & & & 1 & & & & & RHO-ST-46; PNL-10860 \\
\hline $200 \mathrm{E}$ & Sisson-Lu & 299-E24-87 & & & & & & 1 & & & & & RHO-ST-46; PNL-10860 \\
\hline $200 \mathrm{E}$ & Sisson-Lu & 299-E24-88 & & & & & & 1 & & & & & RHO-ST-46; PNL-10860 \\
\hline $200 \mathrm{E}$ & Sisson-Lu & 299-E24-89 & & & & & & 1 & & & & & RHO-ST-46; PNL-10860 \\
\hline $200 \mathrm{E}$ & Sisson-Lu & 299-E24-90 & & & & & & 1 & & & & & RHO-ST-46; PNL-10860 \\
\hline $200 \mathrm{E}$ & Sisson-Lu & 299-E24-91 & & & & & & 1 & & & & & RHO-ST-46; PNL-10860 \\
\hline $200 \mathrm{E}$ & Sisson-Lu & 299-E24-92 & 3 & 3 & 3 & 2 & 2 & 1 & & & & & RHO-ST-46; PNL-10860 \\
\hline $200 \mathrm{E}$ & Sisson-Lu & 299-E24-93 & & & & & & 1 & & & & & RHO-ST-46; PNL-10860 \\
\hline $200 \mathrm{E}$ & Sisson-Lu & 299-E24-94 & & & & & & 1 & & & & & RHO-ST-46; PNL-10860 \\
\hline $200 \mathrm{E}$ & Sisson-Lu & 299-E24-95 & 6 & 6 & 6 & 5 & 5 & 2 & & & & & RHO-ST-46; PNL-10860 \\
\hline $200 \mathrm{E}$ & Sisson-Lu & 299-E24-96 & & & & & & 1 & & & & & RHO-ST-46; PNL-10860 \\
\hline $200 \mathrm{E}$ & Sisson-Lu & 299-E24-97 & & & & & & 1 & & & & & RHO-ST-46; PNL-10860 \\
\hline $200 \mathrm{E}$ & Sisson-Lu & 299-E24-98 & & & & & & 1 & & & & & RHO-ST-46; PNL-10860 \\
\hline $200 \mathrm{E}$ & Sisson-Lu & 299-E24-99 & & & & & & 1 & & & & & RHO-ST-46; PNL-10860 \\
\hline $200 \mathrm{E}$ & Sisson-Lu / UFA & 299-E24-79 & 8 & 8 & & 8 & & & & & & & EJF, RK, Letter Report \\
\hline $200 \mathrm{E}$ & Sisson-Lu / UFA & 299-E24-92 & 3 & 3 & & 3 & & & & & & & EJF, RK, Letter Report \\
\hline $200 \mathrm{E}$ & Sisson-Lu / UFA & 299-E24-95 & 6 & 6 & & 6 & & & & & & & EJF, RK, Letter Report \\
\hline $200 \mathrm{E}$ & Solid Waste & 299-E32-004 & 5 & 6 & 6 & 5 & 5 & & & & & & EJF, RK, Letter Report \\
\hline $200 \mathrm{E}$ & Solid Waste & 299-E34-001 & 7 & 8 & 8 & 7 & 7 & & & & & & EJF, RK, Letter Report \\
\hline
\end{tabular}




\begin{tabular}{|c|c|c|c|c|c|c|c|c|c|c|c|c|c|}
\hline \multirow[b]{2}{*}{ Area } & \multirow[b]{2}{*}{ Site } & \multirow[b]{2}{*}{ Well ID } & \multirow[b]{2}{*}{ Sieve } & \multicolumn{2}{|c|}{ Laboratory Derived Data } & \multirow{2}{*}{$\begin{array}{l}\text { Unsat. } \\
\text { Cond. }\end{array}$} & \multirow{2}{*}{\begin{tabular}{|l} 
Sat. \\
Cond.
\end{tabular}} & \multirow[b]{2}{*}{ Neutron } & \multirow{2}{*}{$\begin{array}{l}\text { Water } \\
\text { Storage }\end{array}$} & \multicolumn{2}{|c|}{ Field Derived Data } & \multirow{2}{*}{ Air } & \multirow[b]{2}{*}{ Reference/Contact } \\
\hline & & & & Bulk/Part Density & Moisture & & & & & Drainage & Moisture Profile & & \\
\hline $200 \mathrm{~W}$ & $200-T-106$ & 299-W10-196 & 10 & 10 & 10 & 10 & 10 & & & & & & EJF, RK, Letter Report \\
\hline $200 \mathrm{~W}$ & 200-UP-2 & 299-W19-95 & & 3 & 3 & 4 & 4 & & & & & & EJF, RK, Letter Report \\
\hline $200 \mathrm{~W}$ & $218-\mathrm{W}-05$ & 299-W07-02 & 4 & 4 & 4 & & & & & & & & WHC-SD-EN-TI-014, PNL-7336 \\
\hline $200 \mathrm{~W}$ & $218-\mathrm{W}-05$ & 299-W10-13 & 2 & 2 & 2 & & & & & & & & WHC-SD-EN-TI-014, PNL-7336 \\
\hline $200 \mathrm{~W}$ & $218-\mathrm{W}-05$ & $299-W 7-9$ & 13 & 13 & 13 & 7 & 7 & & & & & & WHC-SD-EN-TI-014, PNL-7336 \\
\hline $200 \mathrm{~W}$ & BWIP & 200-W19-10 & & 4 & 4 & & & & & & & & EJF, RK \\
\hline $200 \mathrm{~W}$ & RCRA & 299-W10-20 & & 1 & 1 & & & & & & & & EJF, RK \\
\hline $200 \mathrm{~W}$ & RCRA & 299-W10-21 & & 1 & 1 & & & & & & & & EJF, RK \\
\hline $200 \mathrm{~W}$ & RCRA & 299-W18-251 & & 2 & 2 & & & & & & & & EJF, RK \\
\hline $200 \mathrm{~W}$ & RCRA & 299-W18-33 & & 4 & 4 & & & & & & & & EJF, RK \\
\hline $200 \mathrm{~W}$ & RCRA & 299-W23-17 & & 2 & 2 & & & & & & & & EJF, RK \\
\hline $200 \mathrm{~W}$ & VOC & 299-W15-174 & 20 & 1 & & & & & & & $\mathrm{Y}$ & $\mathrm{Y}$ & WHC-SD-EN-TI-202 \\
\hline $200 \mathrm{~W}$ & $\mathrm{VOC}$ & 299-W15-217 & 1 & 1 & 1 & & & & & & $\mathrm{Y}$ & & PNL-9424, WHC-SD-EN-TI-063 \\
\hline $200 \mathrm{~W}$ & VOC & 299-W15-218 & 1 & & & & 1 & & & & $\mathrm{Y}$ & & WHC-SD-EN-TI-202 \\
\hline $200 \mathrm{~W}$ & VOC & 299-W15-219 & 10 & & & & & & & & $\mathrm{Y}$ & & WHC-SD-EN-TI-202 \\
\hline $200 \mathrm{~W}$ & VOC & 299-W15-220 & & & & & & & & & $\mathrm{Y}$ & & WHC-SD-EN-TI-202 \\
\hline $200 \mathrm{~W}$ & VOC & 299-W15-223 & 20 & & & & & & & & & $\mathrm{Y}$ & BHI-00105 \\
\hline $200 \mathrm{~W}$ & VOC & 299-W15-252 & & & & & & & & & $\mathrm{Y}$ & & WHC-SD-EN-TI-202 \\
\hline $200 \mathrm{~W}$ & VOC & 299-W15-96 & 10 & 1 & & & 1 & & & & $\mathrm{Y}$ & $\mathrm{Y}$ & WHC-SD-EN-TI-202 \\
\hline $200 \mathrm{~W}$ & VOC & 299-W18-216 & 3 & 3 & 3 & & & & & & $\bar{Y}$ & & PNL-9424, WHC-SD-EN-TI-063 \\
\hline $200 \mathrm{~W}$ & VOC & 299-W18-246 & 2 & 2 & 2 & 3 & 3 & & & & $\mathrm{Y}$ & & PNL-9424, WHC-SD-EN-TI-063 \\
\hline $200 \mathrm{~W}$ & VOC & 299-W18-247 & 3 & 3 & 3 & 2 & 2 & & & & $\mathrm{Y}$ & & PNL-9424, WHC-SD-EN-TI-063 \\
\hline $200 \mathrm{~W}$ & $\mathrm{VOC}$ & 299-W18-248 & 2 & 2 & 2 & 1 & 1 & & & & & & PNL-9424 \\
\hline $200 \mathrm{~W}$ & VOC / UFA & 299-W15-216 & 7 & 7 & & 7 & & & & & & & PNL-9423 \\
\hline $200 \mathrm{~W}$ & $\mathrm{VOC} / \mathrm{UFA}$ & 299-W15-217 & 8 & 8 & & 8 & & & & & & & PNL-9423 \\
\hline $200 \mathrm{~W}$ & $\mathrm{VOC} / \mathrm{UFA}$ & 299-W15-223 & 7 & 7 & & 7 & & & & & & & PNL-9423 \\
\hline $200 \mathrm{~W}$ & $\mathrm{VOC} / \mathrm{UFA}$ & 299-W18-174 & 6 & 6 & & 6 & & & & & & & PNL-9423 \\
\hline $200 \mathrm{~W}$ & $\mathrm{VOC} / \mathrm{UFA}$ & 299-W18-246 & 7 & 7 & & 7 & & & & & & & PNL-9423 \\
\hline $200 \mathrm{~W}$ & $\mathrm{VOC} / \mathrm{UFA}$ & 299-W18-247 & 8 & 8 & & 8 & & & & & & & PNL-9423 \\
\hline $200 \mathrm{~W}$ & $\mathrm{VOC} / \mathrm{UFA}$ & 299-W18-248 & 6 & 6 & & 6 & & & & & & & PNL-9423 \\
\hline $200 \mathrm{~W}$ & VOC / UFA & 299-W18-249 & 7 & 7 & & 7 & & & & & & & PNL-9423 \\
\hline $200 \mathrm{~W}$ & $\overline{\mathrm{VOC} / \mathrm{UFA}}$ & 299-W18-96 & 6 & 6 & & 6 & & & & & & & PNL-9423 \\
\hline
\end{tabular}




\begin{tabular}{|c|c|c|c|c|c|c|c|c|c|c|c|c|c|}
\hline \multirow[b]{2}{*}{ Area } & \multirow[b]{2}{*}{ Site } & \multirow[b]{2}{*}{ Well ID } & \multirow[b]{2}{*}{ Sieve } & \multicolumn{2}{|c|}{ Laboratory Derived Data } & \multirow{2}{*}{$\begin{array}{l}\text { Unsat. } \\
\text { Cond. }\end{array}$} & \multirow{2}{*}{\begin{tabular}{|l} 
Sat. \\
Cond.
\end{tabular}} & \multirow{2}{*}{ Neutron } & \multirow{2}{*}{$\begin{array}{l}\text { Water } \\
\text { Storage }\end{array}$} & \multicolumn{2}{|c|}{ Field Derived Data } & \multirow{2}{*}{ Air } & \multirow[b]{2}{*}{ Reference/Contact } \\
\hline & & & & Bulk/Part Density & Moisture & & & & & Drainage & Moisture Profile & & \\
\hline $200 \mathrm{~W}$ & $\mathrm{~W}-152$ & 299-W18-251 & & 3 & 3 & & & & & & & & EJF, RK \\
\hline 300 & 300 AREA & Field site & & & 2 & & & & $\mathrm{Y}$ & $\mathrm{Y}$ & & & PNL-2921 \\
\hline 600 & 200-UP-1 & 699-38-68A & & 2 & 2 & 2 & 2 & & & & & & EJF, RK \\
\hline 600 & B-Pond & $216-B-3$ & & 14 & 14 & & & & & & & & EJF, RK \\
\hline 600 & BWTF & Field site & 9 & & $\mathrm{Y}$ & $\mathrm{Y}$ & & & $\mathrm{Y}$ & $\mathrm{Y}$ & & & PNL-6488, PNL-7215, PNL-6750, PNL-4747 \\
\hline 600 & C-018-H & 299-W18-29 & & 2 & 2 & & & & & & & & EJF, RK \\
\hline 600 & C-018-H & 299-W22-45 & & 3 & 3 & & & & & & & & EJF, RK \\
\hline 600 & C-018-H & $699-48-77$ & & 5 & 5 & 2 & 2 & & & & & & EJF, RK \\
\hline 600 & C-018-H & $699-48-77 \mathrm{~A}$ & & 5 & 5 & & & & & & & & EJF, RK \\
\hline 600 & C-018-H & 699-48-77D & & 2 & 2 & & & & & & & & EJF, RK \\
\hline 600 & C-018-H & DH12 & & 4 & 4 & & & & & & & & EJF, RK \\
\hline 600 & C-018-H & DH6 & & 1 & 1 & & & & & & & & EJF, RK \\
\hline 600 & Clastic Dikes & Field site & 17 & 17 & 17 & 7 & 7 & & & & & & HNF-4769 \\
\hline 600 & Clastic Dikes & UFA/field & 5 & 5 & & 5 & & & & 13 & & & BHI-01103 \\
\hline 600 & Deep Lysimeter & Field site & & & & & & $\mathrm{Y}$ & $\mathrm{Y}$ & & $\mathrm{Y}$ & & PNL-7215, BNWL-1711, PNL-5578 \\
\hline 600 & ERDF & 699-32-72B & 3 & 3 & 3 & & & & & & & & WHC-SD-EN-ER-005, EJF, RK \\
\hline 600 & ERDF & 699-35-61A & 3 & 3 & 3 & 3 & 3 & & & & & & WHC-SD-EN-ER-005, EJF, RK \\
\hline 600 & ERDF & $699-35-65 \mathrm{~A}$ & 2 & 3 & 3 & 2 & 2 & & & & & & WHC-SD-EN-ER-005, EJF, RK \\
\hline 600 & ERDF & 699-35-66B & 1 & 2 & 2 & & & & & & & & WHC-SD-EN-ER-005, EJF, RK \\
\hline 600 & ERDF & 699-35-68A & 2 & 2 & 2 & & & & & & & & WHC-SD-EN-ER-005, EJF, RK \\
\hline 600 & ERDF & 699-35-69A & 5 & 5 & 5 & 5 & 5 & & & & & & WHC-SD-EN-ER-005, EJF, RK \\
\hline 600 & ERDF & 699-36-63A & 1 & 3 & 3 & 1 & 1 & & & & & & WHC-SD-EN-ER-005, EJF, RK \\
\hline 600 & ERDF & 699-38-61 & & 5 & 5 & & & & & & & & WHC-SD-EN-ER-005, EJF, RK \\
\hline 600 & ERDF / UFA & 699-32-72B & & 3 & & 3 & & & & & & & EJF, RK, Letter Report \\
\hline 600 & ERDF / UFA & $699-35-61 \mathrm{~A}$ & & 2 & & 2 & & & & & & & EJF, RK, Letter Report \\
\hline 600 & ERDF / UFA & 699-35-65A & & 1 & & 1 & & & & & & & EJF, RK, Letter Report \\
\hline 600 & ERDF / UFA & 699-35-69A & & 2 & & 2 & & & & & & & EJF, RK, Letter Report \\
\hline 600 & ERDF / UFA & 699-36-63A & & 2 & & 2 & & & & & & & EJF, RK, Letter Report \\
\hline 600 & FLTF & N/A & 16 & 16 & 16 & & 16 & $\mathrm{Y}$ & $\mathrm{Y}$ & $\mathrm{Y}$ & & & PNL-6810, PNL-6351, PNL-8675 \\
\hline 600 & Grass Site & Field site & 9 & & $\mathrm{Y}$ & $\mathrm{Y}$ & 8 & & & & & & PNL-6488, PNL-7215, PNL-6750; PNL-5177 \\
\hline 600 & LERF & 216-B-61A & & & 4 & & & & & & & & EJF, RK \\
\hline 600 & McGee / UFA & N/A & & 12 & & 12 & & & & & & & EJF, RK, Letter Report \\
\hline
\end{tabular}




\begin{tabular}{|c|c|c|c|c|c|c|c|c|c|c|c|c|c|}
\hline \multirow[b]{2}{*}{ Area } & \multirow[b]{2}{*}{ Site } & \multirow[b]{2}{*}{ Well ID } & \multirow[b]{2}{*}{ Sieve } & \multicolumn{2}{|c|}{ Laboratory Derived Data } & \multirow{2}{*}{$\begin{array}{l}\text { Unsat. } \\
\text { Cond. }\end{array}$} & \multirow{2}{*}{\begin{tabular}{|c|} 
Sat. \\
Cond.
\end{tabular}} & \multirow{2}{*}{ Neutron } & \multirow{2}{*}{$\begin{array}{c}\text { Water } \\
\text { Storage }\end{array}$} & \multicolumn{2}{|c|}{ Field Derived Data } & \multirow{2}{*}{$\begin{array}{c}\text { Air } \\
\text { Perm. } \\
\end{array}$} & \multirow[b]{2}{*}{ Reference/Contact } \\
\hline & & & & Bulk/Part Density & Moisture & & & & & Drainage & Moisture Profile & & \\
\hline 600 & McGee Ranch & Field site & 12 & & $\mathrm{Y}$ & $\mathrm{Y}$ & & & $\mathrm{Y}$ & & & & PNL-6488, PNL-6314, PNL-6750 \\
\hline 600 & McGhee & $93-11-06$ & & 1 & 1 & & & & & & & & EJF, RK \\
\hline 600 & McGhee & $93-11-08$ & & 1 & 1 & & & & & & & & EJF, RK \\
\hline 600 & McGhee & $93-11-10$ & & 2 & 2 & & & & & & & & EJF, RK \\
\hline 600 & McGhee & $93-11-14$ & & 1 & 1 & & & & & & & & EJF, RK \\
\hline 600 & McGhee & $93-11-16$ & & 1 & 1 & & & & & & & & EJF, RK \\
\hline 600 & McGhee & $93-11-18$ & & 1 & 1 & & & & & & & & EJF, RK \\
\hline 600 & McGhee & $93-11-20$ & & 1 & 1 & & & & & & & & EJF, RK \\
\hline 600 & McGhee & $93-11-25$ & & 2 & 2 & & & & & & & & EJF, RK \\
\hline 600 & McGhee & $93-11-27$ & & 1 & 1 & & & & & & & & EJF, RK \\
\hline 600 & McGhee & $93-11-31$ & & 1 & 1 & & & & & & & & EJF, RK \\
\hline 600 & SLB Site & Field site & & & $\mathrm{Y}$ & $\mathrm{Y}$ & & & & & & & PNL-4747 \\
\hline 600 & SWTF & Field site & & & & & & $\mathrm{Y}$ & $\mathrm{Y}$ & $\mathrm{Y}$ & & & PNL-8955; PNL-6400; PNL-6047, PNL-5578 \\
\hline 600 & U.S. Ecology & 699-35-58 & 10 & 10 & 10 & & & & & & & & PNWD-1127, WHC-SD-EN-TI-019 \\
\hline 600 & U.S. Ecology & $699-36-58 \mathrm{~A}$ & 11 & 11 & 11 & & & & & & & & PNWD-1127, WHC-SD-EN-TI-019 \\
\hline 600 & U.S. Ecology & 699-36-58B & 3 & 3 & 3 & & & & & & & & PNWD-1127, WHC-SD-EN-TI-019 \\
\hline 600 & unknown & $699-43-79$ & & & 1 & & & & & & & & EJF, RK \\
\hline 600 & Unknown & DH12 & & & 3 & & & & & & & & EJF, RK \\
\hline 600 & W-049-H & 699-40-36 & 3 & 3 & 3 & & & & & & & & EJF, RK \\
\hline 600 & W-049-H & 699-41-35 & 1 & 1 & 1 & & & & & & & & EJF, RK \\
\hline 600 & W-049-H & 699-41-39 & 1 & 1 & 1 & & & & & & & & EJF, RK \\
\hline 600 & W-049-H & 699-42-37 & 3 & 3 & 3 & & & & & & & & EJF, RK \\
\hline
\end{tabular}




\section{Appendix D}

\section{Sorted List of Publication Type, Author List, and Publication Year}




\section{Appendix D}

\section{Sorted List of Publication Type, Author List, and Publication Year}

This appendix contains the publications included in the bibliography (Appendix B) sorted by year of publication. The reference number refers to the numbered entries in Appendix B. 


\begin{tabular}{|c|c|c|c|}
\hline $\begin{array}{l}\text { Reference } \\
\text { Number }\end{array}$ & Name & Doc. No. & Year \\
\hline 68 & McHenry & HW-53218 & 1957 \\
\hline 72 & Nelson, Reisenauer & HW-70058 & 1961 \\
\hline 75 & Reisenauer, Nelson & Journal & 1963 \\
\hline 5 & Brownell, Isaacson, Sloughter, Veatch & ARH-2068 & 1971 \\
\hline 15 & Enfield, Hsieh, Warrick & Journal & 1973 \\
\hline 42 & Hseih, Brownell, Reisenauer & BNWL-1711 & 1973 \\
\hline 43 & Hsieh, Reisenauer, Brownell & BNWL-1712 & 1973 \\
\hline 76 & Reisenauer & BNWL-1710 & 1973 \\
\hline 45 & Isaacson, Brownell, Hanson & ARH-2983 & 1974 \\
\hline 78 & Reisenauer, Serne & Communication & 1974 \\
\hline 4 & Brownell, Backer, Isaacson, Brown & ARH-ST-123 & 1975 \\
\hline 77 & Reisenauer, Cearlock, Bryan & BNWL-1713 & 1975 \\
\hline 61 & Last, Easley, Brown & ARH-ST-146 & 1976 \\
\hline 25 & Finlayson & RHO-LD-73 & 1978 \\
\hline 46 & Jones & RHO-ST-15 & 1978 \\
\hline 27 & Gee, Simmons & PNL-2921 & 1979 \\
\hline 89 & Routson, Fecht & WHC-LD-82 & 1979 \\
\hline 28 & Gee, Campbell & PNL3304 & 1980 \\
\hline 7 & Cass, Campbell, Jones & PNL-4015 & 1981 \\
\hline 29 & Gee, Campbell, Wierenga, Jones & PNL3616 & 1981 \\
\hline 44 & Isaacson & RHO-RE-EV-4-P & 1982 \\
\hline 30 & Gee, Kirkham, Downs, Campbell & PNL-5177 & 1984 \\
\hline 47 & Jones, Campbell, Gee & PNL-4896 & 1984 \\
\hline 48 & Jones, Gee & PNL-4747 & 1984 \\
\hline 57 & Kirkham, Gee & PNL-SA-116229 & 1984 \\
\hline 58 & Kirkham, Gee, Jones & Journal & 1984 \\
\hline 91 & Sisson, Lu & RHO-ST-046 & 1984 \\
\hline 31 & Gee, Heller & PNL-5428 & 1985 \\
\hline 32 & Gee, Jones & PNL-5578 & 1985 \\
\hline 39 & Heller, Gee, Myers & PNL-5377 & 1985 \\
\hline 100 & Westinghouse Hanford Company & WHC-IP-0635 & 1986 \\
\hline 2 & Bergeron, Last, Reisenauer & PNWD-1127 & 1987 \\
\hline 59 & Kirkham, Gee, Downs & PNL-6351 & 1987 \\
\hline 62 & Last, Glennon, Young, Gee & PNL-6314 & 1987 \\
\hline 49 & Jones, Serne, Toste & PNL-6400 & 1988 \\
\hline 65 & $\begin{array}{l}\text { Liikala, Aaberg, Aimo, Bates, Gilmore, Jensen, Last, } \\
\text { Oberlander, Olsen et al. }\end{array}$ & PNL-6728 & 1988 \\
\hline 79 & Rockhold, Fayer, Gee & PNL-6488 & 1988 \\
\hline 33 & Gee, Kirkham, Downs, Campbell & PNL-6810 & 1989 \\
\hline 34 & Gee, Rockhold, Downs & PNL-6750 & 1989 \\
\hline
\end{tabular}




\begin{tabular}{|c|c|c|c|}
\hline $\begin{array}{l}\text { Reference } \\
\text { Number }\end{array}$ & Name & Doc. No. & Year \\
\hline 40 & Heller & WHC-EP-0332 & 1989 \\
\hline 92 & Smoot, Szecsody, Sagar, Gee, Kincaid & WHC-EP-0332 & 1989 \\
\hline 3 & Bjornstad & PNL-7336 & 1990 \\
\hline 6 & Campbell, Gee, Rockhold, Kanyid & PNL-7209 & 1990 \\
\hline 80 & Rockhold, Fayer, Gee, Kanyid & PNL-7215 & 1990 \\
\hline 1 & Allen, Howell, Pruitt, Walter, Jensen & Journal & 1991 \\
\hline 60 & Kirkham, Rockhold, Gee, Fayer, Campbell, Frutcher & Journal & 1991 \\
\hline 10 & Conca, Montano (VOC) & Letter Report & 1992 \\
\hline 11 & Connelly, Borghese, Delaney, Ford, Lindberg, Trent & WHC-SD-EN-TI-019 & 1992 \\
\hline 12 & Connelly, Ford, Borghese & WHC-SD-EN-TI-014 & 1992 \\
\hline 13 & Delaney & WHC-SD-EN-DP-065 & 1992 \\
\hline 17 & Fayer, Rockhold, Campbell & Journal & 1992 \\
\hline 35 & Gee, Fayer, Rockhold, Campbell & Journal & 1992 \\
\hline 41 & Hoffman & WHC-SD-EN-TI-054 & 1992 \\
\hline 73 & Pacific Northwest Laboratory & PNL-6894 & 1992 \\
\hline 86 & Rohay, Last, King, Doremus, Lanigan & WHC-SD-EN-TI-063 & 1992 \\
\hline 9 & Conca, Mockler (McGee) & Letter Report & 1993 \\
\hline 66 & Link, Kickert, Fayer, Gee & PNL-8675 & 1993 \\
\hline 81 & Rockhold, Fayer, Heller & PNL-8813 & 1993 \\
\hline 87 & Rohay, Swett, Johnson, Last, Lanigan, Doremus & WHC-SD-EN-TI-202 & 1993 \\
\hline 8 & Conca, Mockler (ERDF) & Letter Report & 1994 \\
\hline 36 & Gee, Wierenga, Andraski, Young, Fayer, Rockhold & Journal & 1994 \\
\hline 37 & $\begin{array}{l}\text { Gee, Freeman, Walters, Ligotke, Campbell, Ward, Link, } \\
\text { Smith, et al. }\end{array}$ & PNL-10275 & 1994 \\
\hline 50 & Jones, Serne & PNL-8955 & 1994 \\
\hline 82 & Rockhold, Rossi, Hill, Gee & Journal & 1994 \\
\hline 98 & Waugh, Theide, Bates, Cadwell, Gee, Kemp & Journal & 1994 \\
\hline 99 & Weekes, Borghese & WHC-SE-EN-ER-005 & 1994 \\
\hline 102 & Wright, Conca, Chen & PNL-9424 & 1994 \\
\hline 16 & Engelman, Lewis, Stromswold, Hearst & PNL-10801 & 1995 \\
\hline 18 & Fayer, Simmons & Journal & 1995 \\
\hline 19 & $\begin{array}{l}\text { Fayer, Lewis, Engelman, Pearson, Murray, Smoot, Randall, } \\
\text { Wegner, Lu }\end{array}$ & PNL-10860 & 1995 \\
\hline 20 & Fayer, Walters & PNL-10285 & 1995 \\
\hline 26 & Freeman & Thesis & 1995 \\
\hline 51 & Khaleel, Freeman & WHC-EP-0883 & 1995 \\
\hline 52 & Khaleel, Relyea, Conca & Journal & 1995 \\
\hline 63 & Last, Serne, LeGore & PNL-10166 & 1995 \\
\hline 83 & Rockhold, Fayer, Gee, Kincaid & PNL-10508 & 1995 \\
\hline 88 & Rohay & BHI-00105 & 1995 \\
\hline 90 & Shields & Thesis & 1995 \\
\hline
\end{tabular}

D. 3 


\begin{tabular}{||c|l|l|c||}
\hline $\begin{array}{c}\text { Reference } \\
\text { Number }\end{array}$ & \multicolumn{1}{|c|}{ Name } & \multicolumn{1}{|c||}{ Doc. No. } & Year \\
\hline \hline & & & \\
95 & $\begin{array}{l}\text { Vermeul, Teel, Amonette, Cole, Frutcher, Gorby, Spane, } \\
\text { Williams, Yabusaki }\end{array}$ & PNL-10633 & 1995 \\
\hline 21 & Fayer, Gee, Rockhold, Freshley, Walters & Journal & 1996 \\
\hline & Narbutovskih, Iwatate, Sweeney, Ramirez, Dailey, Morey, & & \\
71 & Christensen & WHC-SD-EN-TA-004 & 1996 \\
\hline 74 & Ramirez, Daily, Binley, LaBrecque, Roelant & Journal & 1996 \\
\hline 101 & White, Oostrom & PNNL-11216 & 1996 \\
\hline 38 & Gee, Ward, Fayer & Journal & 1997 \\
\hline 53 & Khaleel, Relyea & Journal & 1997 \\
\hline 84 & Rockhold, Fayer, Simmons & Journal & 1997 \\
\hline 96 & Ward, Gee, Link & PNNL-11789 & 1997 \\
\hline 97 & Ward, Gee & Journal & 1997 \\
\hline 85 & Rockhold, Murray, Fayer & Journal & 1998 \\
\hline 22 & Fayer, Murphy, Downs, Khan, Lindenmeirer, Bjornstad & PNNL-13033 & 1999 \\
\hline 24 & Fecht, Bjornstad, Horton, Last, Reidel, Lindsey & BHI-01103 & 1999 \\
\hline 54 & Khaleel & HNF-4769 & 1999 \\
\hline 69 & Meyers, Gee & Journal & 1999 \\
\hline 70 & Meyers, Serne & PNNL-13035 & 1999 \\
\hline 93 & Tyler, Scanlon, Gee, Allison & Journal & 1999 \\
\hline 14 & DynCorp & HNF-7173 & 2000 \\
\hline 23 & Fayer & PNNL-13249 & 2000 \\
\hline 55 & Khaleel & RPP-6296 & 2000 \\
\hline 64 & Last, Horton & PNNL-13149 & 2000 \\
\hline 94 & Valenta, Martin, Horton, Moreno, Ferri, Reidel & PNNL-13328 & 2000 \\
\hline 56 & Khaleel, Relyea & Journal & 2001 \\
\hline 67 & McDonald, Chipman, Mason, Lowry & SEAF-FR-01-261 & 2001 \\
\hline & & & \\
\hline \hline
\end{tabular}




\section{Distribution}

No. of

\section{Copies}

\section{OFFSITE}

P.R. Heller

UFA Ventures Inc./NESTT

2000 Logston Blvd.

Richland, WA. 99352-5300

K.A. Lindsey

Kennedy Jenkins

719 Jadwin Avenue \#28

Richland, Washington

\section{ONSITE}

\section{DOE Richland Operations Office}
M. J. Furman
A6-38
R. D. Hildebrand
A6-38
J. G. Morse
A6-38
K. M. Thompson
A6-38
DOE Public Reading Room (2)
$\mathrm{H} 2-53$

4 Bechtel Hanford, Inc.
L. R. Curry
H0-09
K. R. Fecht
$\mathrm{H} 0-02$
$\mathrm{H} 0-19$
H9-02
A. M. Nazarali

2 CH2M HILL Inc.

K.A. Bergstrom

H9-01

T.H. Mitchell

H9-01
No. of

Copies

8 CH2M HILL Hanford Group, Inc.
M. P. Connelly
E6-35
W. J. McMahon
E6-35
M. N. Jarayssi
H9-03
C. D. Wittreich
E6-35
A. J. Knepp
E6-35
F. M. Mann
E6-35
D. A. Myers
E6-35
V.J. Rohay
E6-35

\section{Fluor Federal Services}

R. Khaleel

E6-17

11 Fluor Hanford, Inc.

J. V. Borghese E6-35

J. D. Davis E6-35

B. H. Ford E6-35

B.A. Howard E6-35

L. C. Swanson E6-35

D. Wilde (5) E6-35

M. I. Wood H8-44

2 U.S. Environmental Protection Agency
D.R. Einan
B5-01
D.A. Faulk
B5-01

3 Washington State Department of Ecology
J. Caggiano
B5-18
D. Goswami
B5-18
J. A. Hedges
B5-18 
No. of

Copies
A. D. Huckaby
B5-18

1 Duratek Federal Services Northwest

M.G. Gardner

H1-11

57 Pacific Northwest National Laboratory

D. B. Barnett

K6-81

M. P. Bergeron

K9-36

R. W. Bryce

J. G. Bush

A. L. Bunn

K. J. Cantrell

C. R. Cole

J. L. Devary

R. L. Dirkes

M. J. Fayer

E. J. Freeman (10)

M. D. Freshley

J. S. Fruchter

G. W. Gee

T. J Gilmore

J.O. Goreham

D. G. Horton

C. T. Kincaid
K9-33

K6-81

K9-36

K6-81

K9-33
No. of

Copies

G. V. Last (5)

K6-81

T. L. Liikala

K6-96

P. E. Long

K9-33

S. P. Luttrell

K6-96

W. J. Martin

K6-81

C. J. Murray

K6-81

R. G. Riley

K6-96

M.J. Rockhold

K9-36

T.D. Scheibe

K9-36

R. M. Smith

K6-96

F. A. Spane, Jr.

K6-96

C.E. Strickland

K9-36

M. D. Sweeney

K6-81

P. D. Thorne

K9-33

A. L. Ward

K9-33

M. D. White

K9-36

B.A. Williams

K6-81

M. D. Williams

K6-36

S. K. Wurstner

K9-36

S. B. Yabusaki

K9-36

J. M. Zachara

P8-55

F. Zhang

K9-33

Hanford Technical Library (2)

P8-55 